\title{
Peroxide-Mediated Oxygenation of Organic Compounds by Fungal Peroxygenases
}

\author{
Martin Hofrichter ${ }^{1, *(D)}$, Harald Kellner ${ }^{1}$, Robert Herzog ${ }^{1}$, Alexander Karich ${ }^{1}$, Jan Kiebist ${ }^{2,3}$, Katrin Scheibner ${ }^{2}$ \\ and René Ullrich ${ }^{1}$ (D)
}

Citation: Hofrichter, M.; Kellner, H.; Herzog, R.; Karich, A.; Kiebist, J.;

Scheibner, K.; Ullrich, R.

Peroxide-Mediated Oxygenation of

Organic Compounds by Fungal

Peroxygenases. Antioxidants 2022, 11, 163. https://doi.org/10.3390/

antiox11010163

Academic Editor: Stanley Omaye

Received: 20 December 2021

Accepted: 11 January 2022

Published: 14 January 2022

Publisher's Note: MDPI stays neutral with regard to jurisdictional claims in published maps and institutional affiliations.

Copyright: (C) 2022 by the authors. Licensee MDPI, Basel, Switzerland. This article is an open access article distributed under the terms and conditions of the Creative Commons Attribution (CC BY) license (https:// creativecommons.org/licenses/by/ $4.0 /)$.
1 Department of Bio- and Environmental Sciences, TU Dresden-International Institute Zittau, Markt 23, 02763 Zittau, Germany; harald.kellner@tu-dresden.de (H.K.); robert.herzog@tu-dresden.de (R.H.); alexander.karich@tu-dresden.de (A.K.); rene.ullrich@tu-dresden.de (R.U.)

2 Institute of Biotechnology, Brandenburg University of Technology Cottbus-Senftenberg, Universitätsplatz 1, 01968 Senftenberg, Germany; jan.kiebist@izi-bb.fraunhofer.de (J.K.); katrin.scheibner@b-tu.de (K.S.)

3 Fraunhofer Institute for Cell Therapy and Immunology, Branch Bioanalytics and Bioprocesses, Am Mühlenberg 13, 14476 Potsdam-Golm, Germany

* Correspondence: martin.hofrichter@tu-dresden.de

\begin{abstract}
Unspecific peroxygenases (UPOs), whose sequences can be found in the genomes of thousands of filamentous fungi, many yeasts and certain fungus-like protists, are fascinating biocatalysts that transfer peroxide-borne oxygen (from $\mathrm{H}_{2} \mathrm{O}_{2}$ or $\mathrm{R}-\mathrm{OOH}$ ) with high efficiency to a wide range of organic substrates, including less or unactivated carbons and heteroatoms. A twice-proline-flanked cysteine (PCP motif) typically ligates the heme that forms the heart of the active site of UPOs and enables various types of relevant oxygenation reactions (hydroxylation, epoxidation, subsequent dealkylations, deacylation, or aromatization) together with less specific one-electron oxidations (e.g., phenoxy radical formation). In consequence, the substrate portfolio of a UPO enzyme always combines prototypical monooxygenase and peroxidase activities. Here, we briefly review nearly 20 years of peroxygenase research, considering basic mechanistic, molecular, phylogenetic, and biotechnological aspects.
\end{abstract}

Keywords: unspecific peroxygenases; UPO; EC 1.11.2.1; monooxygenases; peroxidases; hydroxylation; epoxidation; dealkylation

\section{Introduction}

According to enzyme nomenclature, unspecific peroxygenases (UPOs, EC 1.11.2.1) belong to the sub-subclass of oxidoreductases that act 'with $\mathrm{H}_{2} \mathrm{O}_{2}$ as acceptor, one oxygen atom of which is incorporated into the product' (https:/ / www.qmul.ac.uk/sbcs/iubmb/ enzyme/EC1/11/2; (accessed on 20 December 2021) [1]). They bear a cysteine-ligated heme in the active site (heme-thiolate proteins/HTP) and behave 'promiscuously' with respect to oxygen transfer reactions, i.e., one individual UPO protein may catalyze dozens of different oxyfunctionalizations in dependence on the geometry of its heme access channel and the structure of the particular substrate molecules [2-4]. The first UPO was discovered as an 'untypical' veratryl-alcohol-oxidizing haloperoxidase in the Black Poplar mushroom (Agrocybe aegerita, nowadays Cyclocybe aegerita) [5], a hardwood and leaf-litter-dwelling edible fungus belonging to the large basidiomycetous order of Agaricales (which typically form mushrooms and 'toadstools' as fruiting organs) [6]. More wild-type UPOs were later found in cultures of other filamentous fungi (including the ink-cap Coprinellus radians, the Pinwheel mushroom Marasmius rotula, and the ubiquitous ascomycetous mold Chaetomium globosum) [7,8]. Moreover, chloroperoxidase (CPO, EC 1.11.1.10), secreted by the ascomycetous sooty mold Caldariomyces fumago, which had been a 'phylogenetic and catalytic orphan' for a long time, turned out to be a special type of UPO [8-10]. 
Though UPOs oxygenate diverse substrates simply with peroxide as a co-substrate, the catalyzed oxyfunctionalizations proceed mostly with high selectivity. In addition, the UPOs tested so far have shown remarkable insensitivity regarding organic solvents and towards several physicochemical factors, making them interesting catalysts for biotechnology and organic synthesis. The major drawback remains their limited availability (there are no commercial UPOs on the market) and there are only 20 UPOs available even at the laboratory scale (see Table 1 below). A second shortcoming is their sensitivity towards high peroxide concentrations, which causes enzyme inactivation. While the former problem may be solved in the near future by new and optimized expression techniques, the second issue is subject to intelligent reaction design and improved peroxide supply under reaction conditions.

Key findings reported here are the outcome of five integrated projects of the European Union (BIORENEW, PEROXICATS, INDOX, ENZOX2, SUSBIND) as well as of several German and Spanish national projects with participants from academia, research institutions and industry of nine European countries as well as the US [11-14]. This includes basic information on the structure, function and phylogeny of UPOs, as well as approaches addressing their biotechnological potential. Respective findings have been published in around 100 scientific articles and dozens of patents since 2004 [5,15-23]; previous reviews documenting the then-current state of peroxygenase research or addressing specific aspects of peroxygenase catalysis and expression were published in 2006, 2010, 2014, 2015, 2019, 2020 , and $2021[2,8,10,24-31]$.

\section{UPO Production and Purification}

The first UPO of Cyclocybe (syn. Agrocybe) aegerita was found while cultivating the fungus in an agitated soybean-based complex medium [5]. Three major isoforms of this secreted enzyme, oxidizing various aryl alcohols, phenolics, ABTS, and halides, were present in the culture broth and could be separated and purified to homogeneity by several ultrafiltration and chromatographic steps using ion exchangers and FPLC devices [32]. Meanwhile, the genome of $C$. aegerita has been sequenced, revealing 18 different UPO genes [33]. Further screenings in complex media with varying amounts of soybean flour and soy extracts, yeast extract, peptones of different origin, alfalfa pellets, and/or sugars (glucose, fructose) led to the discovery of more UPOs from agaric Basidiomycota (wood and leaf-litter dwellers), e.g., Cyclocybe (Agrocybe) parasitica (unpublished result), Marasmius rotula [34] and M. wettsteinii [35], Coprinellus radians and Coprinopsis verticillata [36], and Candolleomyces (Psathyrella) aberdarensis [29,37]. The production of an ascomycetous wild-type UPO in appreciable amounts has so far only been successful in the case of the cellulolytic mold Chaetomium globosum [38]. Molecular masses and isoelectric points of characterized wildtype UPOs range from 23 to $64 \mathrm{kDa}$ and from $\mathrm{pH} 4.0$ to 9.0, respectively (Table 1). As far as studied, $N$-glycosylation at different sites of the apo-protein is of the 'high-mannose' type and can account for up to $20 \%$ of the mass of the mature enzyme [39,40].

The UPO concentrations secreted by these wild-type fungi in surface or agitated batches can greatly vary, not only in dependence on the particular fungal strain and culture conditions but also from cultivation approach to cultivation approach (between 2 and $600 \mathrm{mg} \mathrm{L}^{-1}$, corresponding to 50-40,000 $\mathrm{U} \mathrm{L}^{-1}$ veratryl alcohol oxidation units) $[5,34,36,38,41]$. The latter suggests that-in addition to external culture conditions (i.e., composition and agitation of the liquid medium, dioxygen supply, $\mathrm{pH}$, temperature, etc.) - a kind of autoregulation ('internal clock') in the fungus may influence UPO synthesis and secretion. As an example, Figure 1 describes the time courses of UPO activity in cultures of Cyclocybe (Agrocybe) parasitica and Marasmius wettsteinii (unpublished results). 

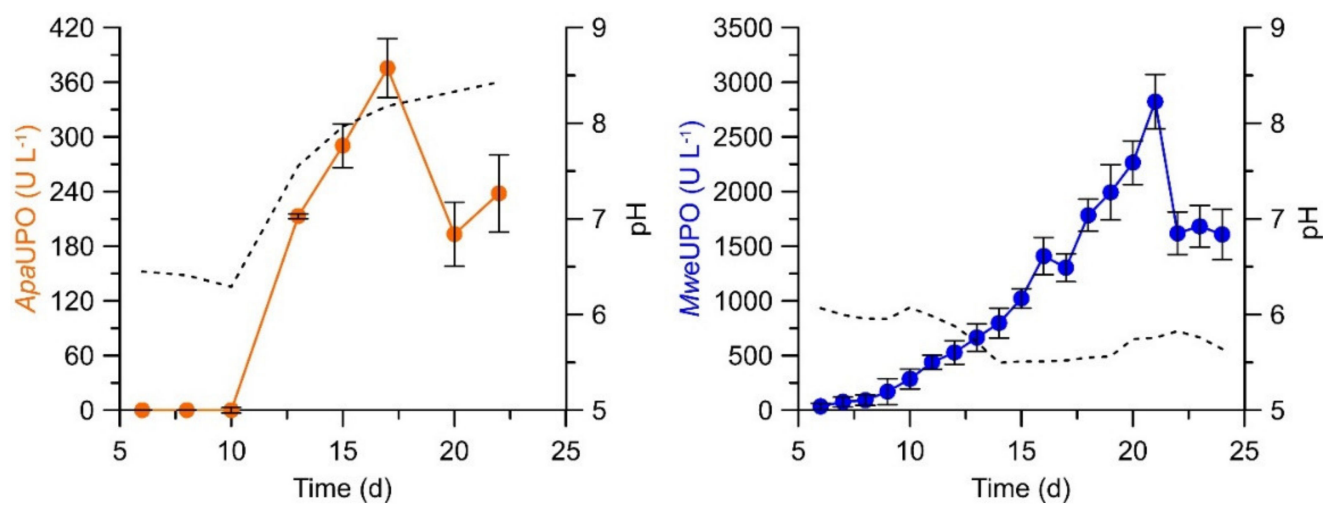

Figure 1. UPO activities of Cyclocybe (Agrocybe) parasitica (ApaUPO) and Marasmius wettsteinii (MweUPO) measured with veratryl alcohol (which is oxidized into veratraldehyde) in agitated liquid cultures (500 mL flasks, $100 \mathrm{rpm}$, medium: $20 \mathrm{~g} \mathrm{~L}^{-1}$ soybean flour suspended in water).

All studies carried out to date indicate that fungal wild-type strains secrete 'short' UPOs of family I in higher amounts than 'long' UPOs of family II (with regard to UPO families, compare the phylogeny below) (Table 1). Efforts to improve homologous UPO production are still ongoing, particularly with respect to the identification of specific elicitor/inducer molecules and the use of naturally fast-growing Ascomycota (molds) and basidiomycetous yeasts with UPO genes in their genomes (e.g., Aspergillus, Chaetomium, Trichoderma, Rhodotorula). Although several attempts have been made to identify specific substances and conditions that increase UPO levels, it is still unclear which mechanisms actually trigger their production and secretion [42]. More importantly, it should be noted that not only is the total amount of UPO protein $(\mathrm{mg})$ formed in a batch important, but also its specific activity $\left(\mathrm{U} \mathrm{mg}^{-1}\right)$ as a relative proportion (\% of total protein) in the original culture liquid, since this is a measure for the natural UPO 'enrichment' during cultivation. In particular, in culture media that are rich in peptides and proteins (soybean components, peptones), these values can be unfavorable compared to synthetic media.

In addition to homologously produced wild-type UPOs, a steadily increasing number of recombinant UPOs have become available over the last few years. Thus far, they belong to 14 fungal species and the expression hosts are molds (Aspergillus oryzae, A. nidulans, A. niger), ascomycetous yeasts (Saccharomyces cerevisiae and methylotrophic Pichia (Komagataella) pastoris), as well as the Gram-negative bacterium Escherichia coli [8] (Table 1). The world's leading enzyme supplier, Novozymes A/S (Copenhagen, DK), prepared the first recombinant UPO from the ink-cap Coprinopsis cinerea in A. oryzae and tested its suitability for oxyfunctionalizing syntheses $[12,20]$; later, a second recombinant UPO from the thermophilic soil ascomycete Humicola insolens (syn. Mycothermus thermophilus, Scytalidium thermophilum) was produced using the same host [38,43,44].

Miguel Alcalde and co-workers were the first who successfully applied directed evolution in the yeast $S$. cerevisiae to generate UPO mutants with improved synthetic properties, among them Pada-I, Jawa, and Solo, AaeUPO mutants with better performance and decreased peroxidative activity. The Pada-I variant can be produced at levels of up to $300 \mathrm{mg} \mathrm{L}^{-1}$ in a second yeast, Pichia pastoris (tandem-expression system), and is useful when the targeted products (or already the substrates) bear reactive phenolic groups that would rapidly undergo oxidation by the peroxidative activity of UPO (one-electron oxidation) [45-48]. The latter leads to the formation of phenoxy radicals and subsequently to undesired coupling products and quinones. This shortcoming can be circumvented by applying radical scavengers such as ascorbic acid, which reduce the radicals formed $[49,50]$, but engineered UPOs offer a more elegant way to prevent these side activities [51]; furthermore, these molecular techniques can be applied to improve other UPO shortcomings, such as stability in organic solvents [52]. 
Table 1. Survey on wild-type and recombinant UPOs from 18 fungal species available so far.

\begin{tabular}{|c|c|c|c|c|c|c|}
\hline Enzyme & Donating Organism & Expression System & Mutant & $\begin{array}{c}\text { Molecular } \\
\text { Weight } \\
\text { (kDa) }\end{array}$ & $\begin{array}{c}\text { Secretion } \\
\text { Level } \\
\left(\mathrm{mg} \mathrm{L}^{-1}\right)\end{array}$ & Ref. \\
\hline AaeUPO & $\begin{array}{l}\text { Agrocybe aegerita } \\
\text { (syn. Cyclocybe) }\end{array}$ & Wild-type & No & $45-46\left(37^{*}\right)$ & 10 & {$[5,32,39]$} \\
\hline $\begin{array}{l}\mathrm{rAaeUPO} \\
(\mathrm{PaDa}-\mathrm{I})\end{array}$ & A. aegerita & $\begin{array}{c}\text { Saccharomyces cerevisiae, } \\
\text { Pichia pastoris }\end{array}$ & Yes & 51 & 300 & {$[45,46,53]$} \\
\hline rAaeUPO & A. aegerita & P. pastoris & No & - & 290 & [54] \\
\hline rAniUPO & Aspergillus niger & P. pastoris & No & 60 & - & [55] \\
\hline rCciUPO & Coprinopsis cinerea & Aspergillus oryzae & No & 44 & - & {$[12,18]$} \\
\hline CglUPO & Chaetomium globosum & Wild-type & No & 36 & 44 & {$[38]$} \\
\hline rCglUPO & C. globosum & A. oryzae & No & - & - & [18] \\
\hline CPO (LfuUPO) & $\begin{array}{l}\text { Leptoxyphium fumago } \\
\text { (syn. Caldariomyces) }\end{array}$ & Wild-type & No & $40-42$ & 600 & {$[56-58]$} \\
\hline $\mathrm{r} L f u \mathrm{UPO}$ & L. fumago & A. niger & No & $45-50$ & 10 & [59] \\
\hline CraUPO & Coprinellus radians & Wild-type & No & $43-45\left(27^{*}\right)$ & - & [36] \\
\hline CveUPO & Coprinopsis verticillata & Wild-type & No & $40\left(23^{*}\right)$ & - & [41] \\
\hline rCviUPO & Collariella virescens & A. oryzae, Escherichia coli & No & - & 7 & {$[18,60]$} \\
\hline $\mathrm{rDcaUPO}$ & Daldinia caldariorum & A. oryzae, E. coli & No & - & 3 & {$[18,60]$} \\
\hline rHinUPO & Humicola insolens & A. oryzae & No & - & - & {$[18,38]$} \\
\hline HspUPO & Hypoxylon sp. EC38 & S. cerevisiae & No & $55(28 *)$ & 200 & {$[61]$} \\
\hline MroUPO & Marasmius rotula & Wild-type & No & $32\left(27^{*}\right) ; 64^{* *}$ & 450 & {$[34,62]$} \\
\hline MweUPO & M. wettsteinii & Wild-type & No & $32 ; 62 * *$ & - & [35] \\
\hline rMfeUPO & Myceliophthora fergusii & A. oryzae & No & - & - & [18] \\
\hline rMhiUPO & M. hinnulea & A. oryzae & No & - & - & [18] \\
\hline PabUPO & $\begin{array}{l}\text { Candolleomyces aberdarensis } \\
\text { (syn. Psathyrella aberdarensis) }\end{array}$ & Wild-type & No & $40-41$ & - & {$[29,63]$} \\
\hline rPabUPO-I & & S. cerevisiae & Yes & 47 & 14 & [64] \\
\hline$(\mathrm{Grogu})$ & C. aberdarensis & P. pastoris & Yes & - & 290 & [64] \\
\hline rPabUPO-II & C. aberdarensis & S. cerevisiae & No & 45 & 5.4 & {$[64]$} \\
\hline rPviUPO & Pestalotiopsis virgatula & A. oryzae & No & - & - & [18] \\
\hline rThyUPO & Thielavia hyrcaniae & A. oryzae & No & - & - & [18] \\
\hline
\end{tabular}

${ }^{*}$ Deglycosylated protein; ${ }^{* *}$ dimer.

Using the Saccharomyces-Pichia expression system, UPOs from A. aegerita, Marasmius rotula (M. Alcalde, personal communication), and Candolleomyces aberdarensis (rPabUPO with interesting $\mathrm{pH}$ stability) have been produced at levels of up to $300 \mathrm{mg} \mathrm{L}^{-1}[54,64]$.

A modified Saccharomyces-Pichia system has recently been applied to express four active peroxygenases (rMroUPO, rCglUPO, rMthUPO, and rTteUPO; Table 1) using a 'Golden Gate platform' consisting of three modules (signal peptide library-module 1, UPO genes-module 2, and protein tags-module 3) $[65,66]$. The same group used the Saccharomyces system to engineer one of the newly expressed enzymes (rMthUPO) from the sordariomycete Myceliophthora thermophila (Corynascus heterothallicus) [67]. Notably, this fungus has been a source of industrial enzymes (e.g., cellulase, pectinases, laccase) for many years $[68,69]$.

All in all, for the time being, the Pichia expression system [70] seems to be the production system of choice, and it has been demonstrated to be applicable also without pre-engineering in Saccharomyces, e.g., for a UPO of the soft-rot fungus Hypoxylon sp. EC38 [61], as well as for the aforementioned UPOs from C. aberdarensis and a UPO from an Aspergillus niger strain [55,64]. Pilot-scale production (2500 L) of recombinant AaeUPO with Pichia has recently been demonstrated, resulting in over $700 \mathrm{~g}$ enzyme within six days [54].

Angel T. Martínez and co-workers have developed an expression system based on E. coli as a bacterial host. They were able to express native and mutated UPOs from Collariella virescens (syn., Chaetomium virescens) and Daldinia caldariorum in this system, which have not been available as wild-type enzymes before [22,60]. Recombinant UPOs produced in E. coli, however, are still limited in the obtained amounts and lacking glyco- 
sylation, which may affect physicochemical properties such as water solubility and $\mathrm{pH}$ stability. On the other hand, UPO properties may also change when they are expressed in S. cerevisieae or P. pastoris. For example, the molecular mass of recombinant AaeUPO (Pada-I) increased from 45-46 kDa to 51-52 kDa due to over-glycosylation (Table 1). Such different or lacking glycosylation can even affect the kinetic parameters, as has been already observed for fungal aryl alcohol oxidases [71].

A valuable summary on the heterologous expression of unspecific peroxygenases in all available hosts as well as in wild-type fungi has recently been published by [72] Despite all undoubted efforts in the field of heterologous expression, there is no commercial UPO preparation available at present. It is conceivable, however, that this bottleneck will be overcome in the near future by further improving existing expression systems and by developing new expression strategies, e.g., cell-free approaches based on isolated ribosomes $[23,73,74]$.

\section{UPO Characteristics and Catalytic Cycles}

All UPOs purified and characterized so far have characteristic absorption properties in the visible and UV range, with a striking maximum (Soret band) in the ground state (native enzyme) between 416 and $421 \mathrm{~nm}$. Additional local maxima $(\alpha, \beta, \delta$ bands) appear around 570, 540, and $360 \mathrm{~nm}$, respectively. As an example, the so far unpublished UV-Visspectrum of the UPO of Cyclocybe (Agrocybe) parasitica is shown in Figure 2, along with the electrophoretic characteristics of the corresponding protein.

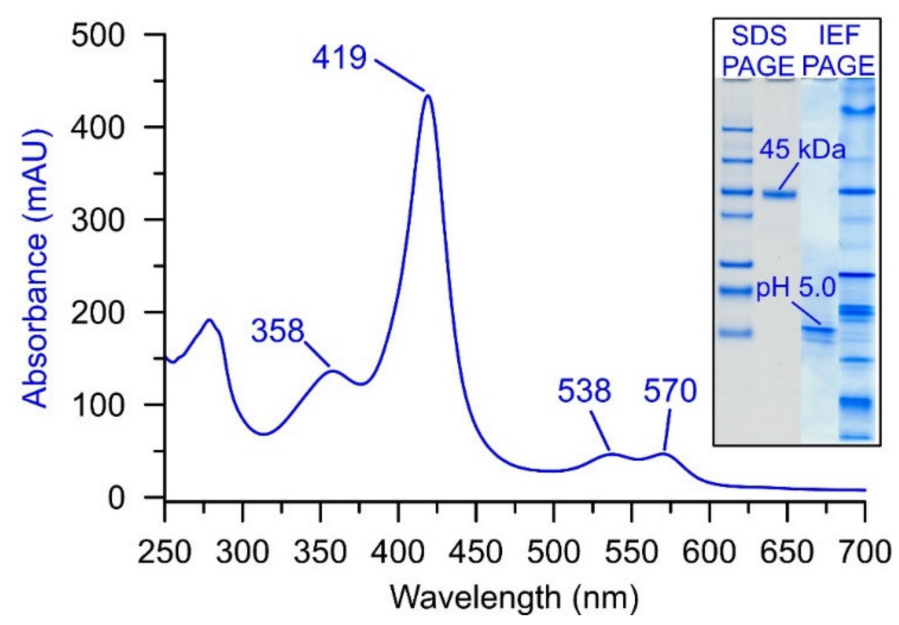

Figure 2. UV-Vis spectrum of a purified wild-type UPO from Cyclocybe (Agrocybe) parasitica (ApaUPO) with the characteristic Soret band at $419 \mathrm{~nm}$ and the $\alpha, \beta$, and $\delta$ bands at 570, 538, and $358 \mathrm{~nm}$, respectively. The inset shows the corresponding electrophoresis results: SDS-PAGE (left lanes) with molecular mass standards and the $45 \mathrm{kDa}$ band; isoelectric focusing (IEF)-PAGE (right lanes) with the indicative $\mathrm{pI}$ band at pH 5.0 and IEF markers.

After reduction of UPO-heme $\left(\mathrm{Fe}^{3+} \rightarrow \mathrm{Fe}^{2+}\right.$ ) with sodium dithionite and flushing with carbon monoxide (CO), the Soret band shifts towards a longer wavelength $(445-448 \mathrm{~nm})$ but without reaching the prototypical $450 \mathrm{~nm}$ mark of eponymous monooxygenases (P450s, CYPs) $[2,5,29,75,76]$.

The crystal structures of UPOs from A. aegerita (wild-type, recombinant, and mutant proteins), M. rotula, and, very recently, from recombinant Hypoxylon sp. EC38 have been solved, revealing a compact spherical shape dominated by $\alpha$-helices and containing a heme-stabilizing magnesium $\left(\mathrm{Mg}^{2+}\right)$ and a highly conserved PCP motif $[3,40,61,62,77]$. The latter perfectly exposes a cysteine flanked by two 'chain-breaking' prolines towards the heme iron. The heme access channels of UPOs are lined with hydrophobic amino acid residues (e.g., Phe or Leu/Ile/Val) and their molecular architecture is crucial for the substrate specificity of the respective enzyme $[29,35,38]$. 
Three examples of such structural models of UPOs can be found in Figure 3.
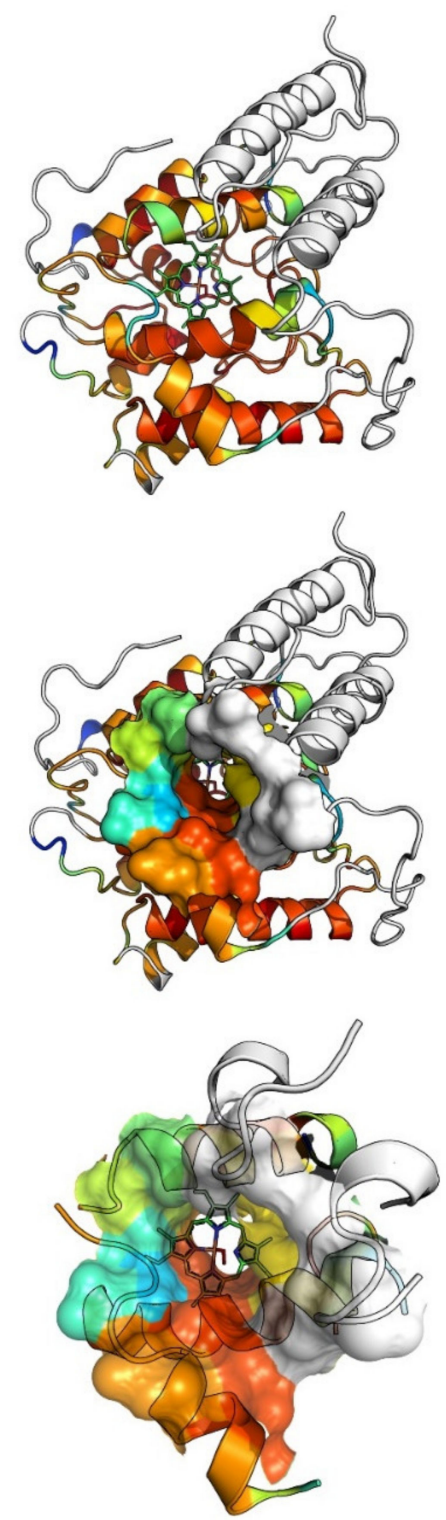
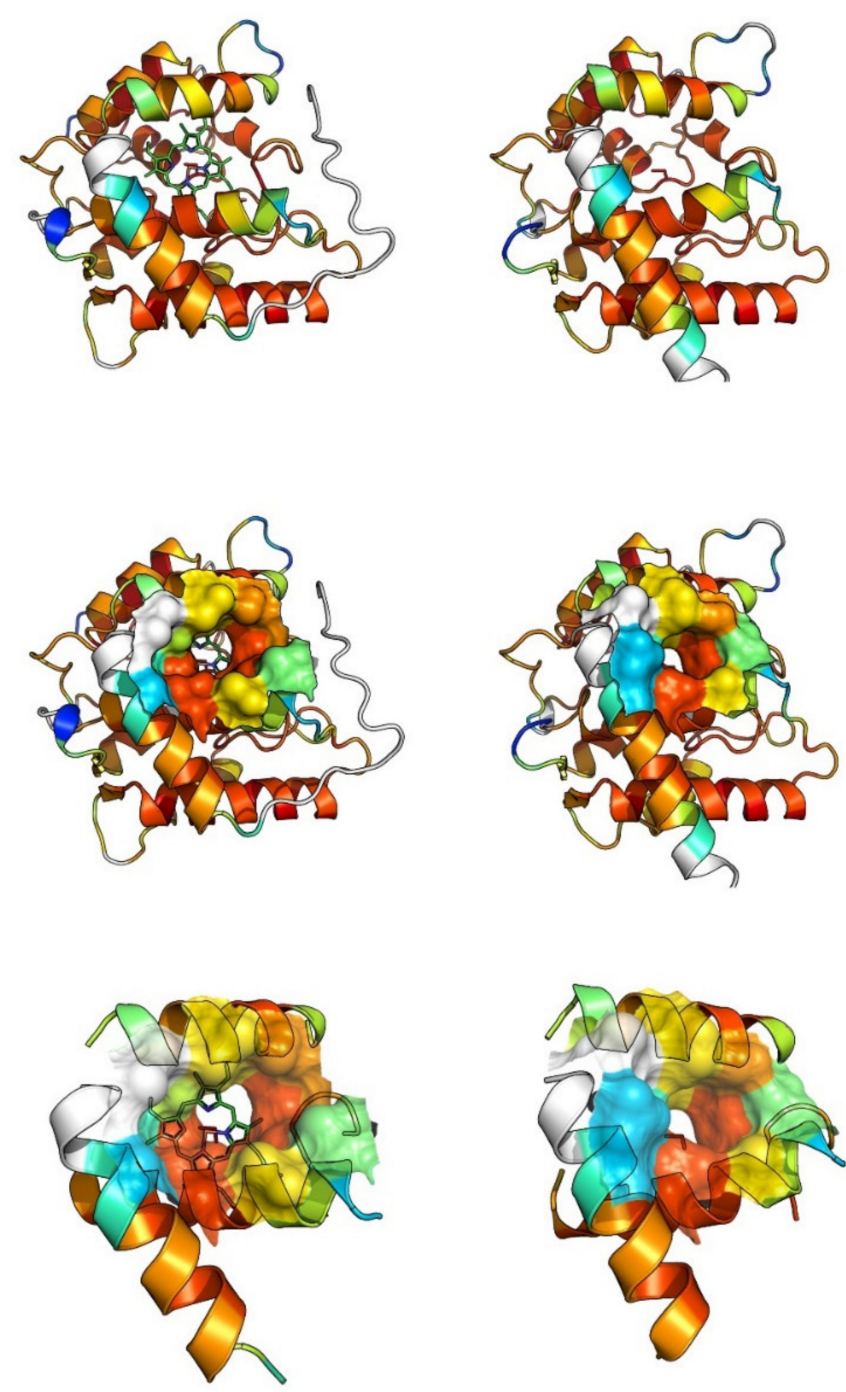

Figure 3. Models of three unspecific peroxygenases (UPOs). Left: Cyclocybe (Agrocybe) aegeritaAaeUPO, middle: Marasmius rotula-MroUPO, right: Chaetomium globosum-CglUPO. Upper row: ribbon representation, middle row: mixed surface and ribbon representation, lower row: heme access channels. To predict the tertiary structure of CglUPO, the ColabFold [78] 'AlphaFold2_mmseqs2' notebook was used (accessed Nov 2021). Both amber relaxation/refinement and the usage of templates were selected and the input sequence was queried vs. the 'UniRef'+'Environmental' databases. The Alphafold2_mmseqs2 notebook is a variation of the AlphaFold2 prediction architecture [79]. PyMOL (PyMOL Molecular Graphics System, Version 2.5.2 Schrödinger, LLC) was used to visualize the resolved protein structures of AaeUPO (PDB\#: 2YOR chain A), MroUPO (PDB\#: 5FUK chain A), as well as the highest-ranked predicted structure of CglUPO. The PyMOL plugin PyMOD3.0 [80] was used to align the proteins with the built-in SALIGN module of the MODELLER [81] package. To find structurally conserved regions (SCRs) between the three proteins, the SCR_FIND algorithm [82] was used on the alignment of SALIGN (SC score limit $=3.0$, sliding window size $=3$, gap penalty $=100$ ). SCR_FIND colors residues according to the rainbow colors, ranging from blue (low structural conservation) to red (higher structural conservation). Residues that were not found to be conserved among all proteins are shown in white. 
Meanwhile, 3D modeling based on primary sequences and known crystal structures has reached such quality that it can be used to obtain reliable protein structures $[83,84]$.

Most UPOs are mono[per]oxygenases acting outside the fungal cells and transferring a peroxide-borne oxygen atom (H-O-O-R) to diverse organic substrates. The target substrates are subject to hydroxylation, epoxidation, and heteroatom oxygenation, and, in turn, to spontaneous dealkylation, deacylation, or (re-)aromatization [25].

In addition, UPOs catalyze one-electron oxidations, i.e., the abstraction of single electrons (mostly together with protons) from susceptible functionalities such as phenolic hydroxyl groups, analogous to conventional peroxidases (Figure 4). Often, the product spectra of UPOs, e.g., regarding the oxidation of organopollutants and drugs, resemble those of cytochrome P450 monooxygenases (P450s, CYPs) that act, among others, as intracellular detoxification enzymes in the liver of vertebrates $[7,85,86]$.

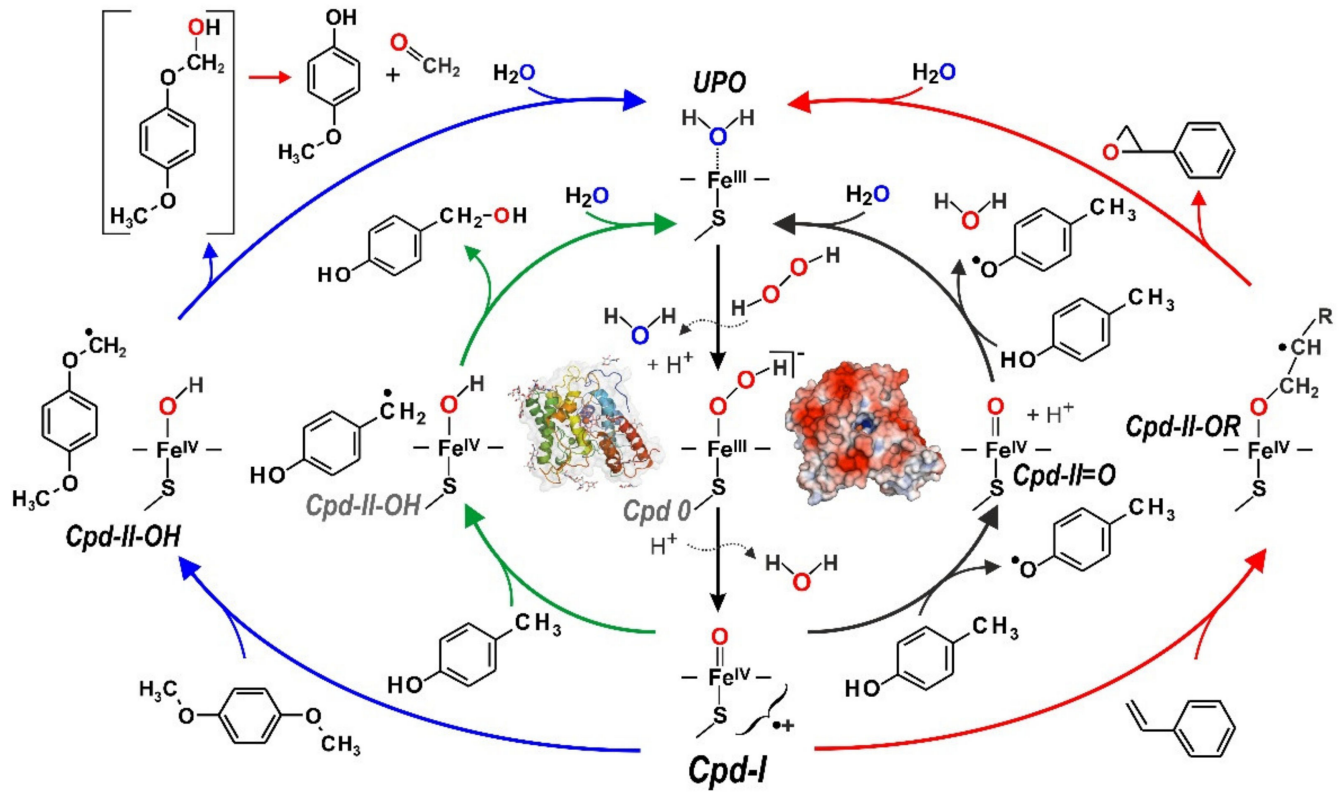

Figure 4. Catalytic cycles of an unspecific peroxygenase (UPO). Using three different substrates ( $p$-cresol, $p$-hydroxyanisole, styrene), the scheme shows three possible oxygenations and a oneelectron oxidation, which can be catalyzed by a single UPO, e.g., by the model enzyme from Cyclocybe (Agrocybe) aegerita (AaeUPO). Left: benzylic hydroxylation of $p$-cresol to 4-hydroxybenzyl alcohol (inner green arrows), $O$-dealkylation of 1,4-dimethoxybenzene to $p$-hydroxyanisole (outer blue arrows) via an unstable hemiacetal intermediate (in square brackets); right: epoxidation of styrene to styrene oxide (outer red arrows) and oxidation of $p$-cresole to two corresponding phenoxy radicals (inner black arrows). All reactions proceed via a short-lived compound 0 (Cpd-0) state and reactive compound I (Cpd-I) as the key intermediate but differ regarding the compound II states (Cpd-II). While hydroxylation and $\mathrm{O}$-dealkylation proceed via protonated compound II ( $\mathrm{Cpd}-\mathrm{OH})$, epoxidation requires the transitional formation of a compound II that binds the substrate as C-radical (Cpd-II$\mathrm{OR}^{\bullet}$ ) and the second phenolic substrate molecule is oxidized by peroxidase-typical, deprotonated compound II (Cpd-II = O) (modified according to $[8,11,28,29,87]$ ).

Figure 4 illustrates the mechanisms of UPO-catalyzed oxygenation and oxidation reactions by the exemplary substrates $p$-cresol (4-methylphenol), 1,4-dimethoxybenzene ( $p$-methoxyanisole), and styrene (vinylbenzene). The former undergoes both benzylic hydroxylation and oxidation to the corresponding phenoxy radical $[10,88]$, the aromatic diether is O-dealkylated (via an unstable hemiacetal intermediate) [89], and styrene's side chain is subject to epoxidation [90]. The reactive UPO key species is, in each case, the so-called compound I (Cpd-I), a high-valent oxoferryl cation $\pi$-radical complex of heme, [heme $]^{\bullet+}-\mathrm{Fe}^{4+}=\mathrm{O}$, that is formed after the binding and heterolytic cleavage of $\mathrm{H}_{2} \mathrm{O}_{2}[11,91]$. UPO Cpd-I is an extremely strong oxidant that attacks $\mathrm{C}-\mathrm{H}$ bonds $\left(\mathrm{sp}^{3}\right), \mathrm{C}=\mathrm{C}$ 
bonds ( $\mathrm{sp}^{2}, \pi$-systems and aromatics), S-/N-heteroatoms, and phenolic $\mathrm{OH}$-groups via radical formation $\left(\mathrm{C}^{\bullet}, \mathrm{S}^{\bullet}, \mathrm{N}^{\bullet}, \mathrm{O}^{\bullet}\right)$. Subsequently, rebound mechanisms lead to the transfer of oxygen (peroxygenation of a C/S/N atom or epoxide formation) or to the formation of a second $\mathrm{O}^{\bullet}$ radical (phenol oxidation) [29]. The reactions taking place thus correspond to a combination of the so-called 'peroxide shunt' of certain P450s and the catalytic cycle of typical heme peroxidases [92].

\section{Selected Reactions Catalyzed by UPOs}

UPOs catalyze diverse oxygen transfer reactions in the peroxygenase mode, including the hydroxylation of $\mathrm{sp}^{3}$-carbons $(\mathrm{C}-\mathrm{H})$ and epoxidation of $\mathrm{sp}^{2}$-carbons $(\mathrm{C}=\mathrm{C})$, some of which may undergo spontaneous further reactions, such as $\mathrm{O}$ - and $\mathrm{N}$-dealkylation, epoxide opening, deacylation, or aromatization. Heteroatoms in organic molecules, such as sulfur (C-S) and nitrogen (C-N), are the subjects of oxygen transfer as well, and inorganic halides $\left(\mathrm{X}^{-}\right)$can be oxidized into hypohalites $\left(\mathrm{OX}^{-}\right)$, which in turn halogenate other molecules (haloperoxidase mode). In the 'classic' peroxidase mode, UPOs oxidize prototypical substrates such as ABTS, phenolics, aromatic amines, and luminol by one-electron oxidations [28,29]. Figure 5 summarizes UPO-catalyzed reactions in a simplified scheme; an overview of the kinetic properties of UPOs, whose catalytic efficiencies $\left(\mathrm{k}_{\mathrm{cat}} / \mathrm{K}_{\mathrm{m}}\right)$ for oxygenations range between $10^{3}$ and $10^{6} \mathrm{M}^{-1} \mathrm{~s}^{-1}$, is given in Hofrichter et al. (2015) [2].

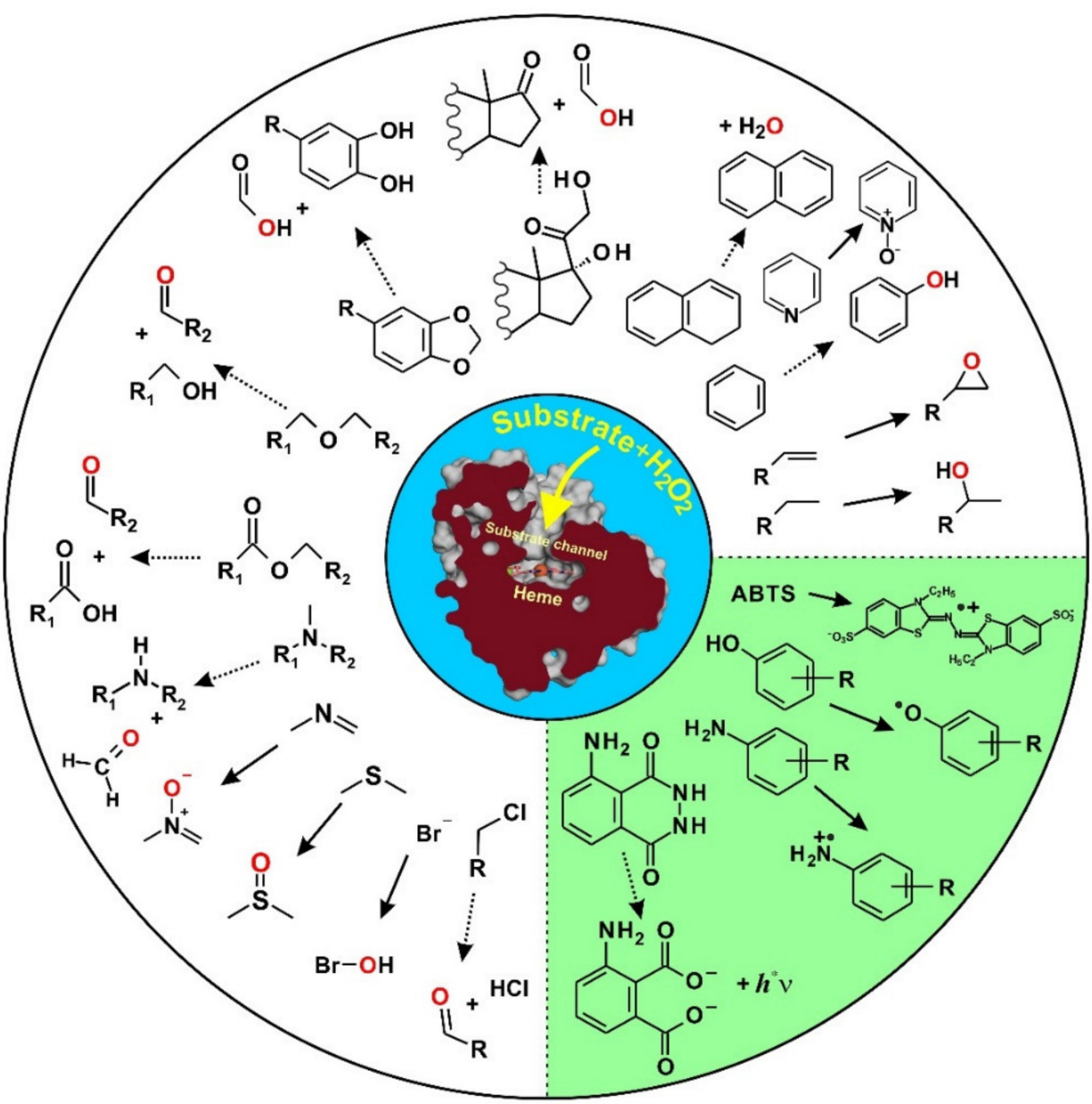

Figure 5. Reactions catalyzed by unspecific peroxygenases (UPOs). Reactions on the green background are one-electron oxidations resulting in unstable products (radicals). All other reactions are related to oxygen transfer from peroxide to diverse target substrates, resulting in hydroxylated, epoxidized, or cleaved products, modified according to [2,25,29]. 
Only a small group of UPOs have been demonstrated to catalyze a range of oxygenations at different types of carbons, which is reflected by numerous original papers $(>80)$ and review articles dealing with UPO-catalyzed conversions since their discovery in 2004; some relevant review articles covering, in addition to biochemical and synthetic, also biosensor-related findings can be found in $[2,7,10,24,25,29-31,93-101]$.

Typically, the UPO-mediated oxidation of $\mathrm{C}$ atoms (e.g., of an appropriate alkyl moiety such as benzylic $\mathrm{CH}_{3}$ or $\mathrm{CH}_{2}-\mathrm{R}$ ) begins with the insertion of oxygen from hydrogen peroxide $(\mathrm{H}-\mathrm{O}-\mathrm{O}-\mathrm{H})$, resulting in the corresponding alcohols $\left(\mathrm{CH}_{2}-\mathrm{OH}, \mathrm{CH}_{2}-\mathrm{OH}-\mathrm{R}\right)$. These primary and secondary alcohols can be subject to further hydroxylation at the same carbons, which leads to the formation of the corresponding gem-diols [carbonyl hydrates $\left.\mathrm{CH}-(\mathrm{OH})_{2}\right]$, which are in equilibrium with aldehydes $(\mathrm{CHO})$ and ketones $(\mathrm{C}=\mathrm{O})$, respectively. The aldehyde functionality in turn can be hydroxylated again to form the corresponding $\mathrm{COOH}$ group (carboxylic acid) (Figure 6). The first hydroxylation may proceed entantioselectively, as in the case of ethylbenzene and AaeUPO, affording preferably (R)-1-phenylethanol [90,102].<smiles>CCc1ccccc1</smiles><smiles>COC(C)c1ccccc1</smiles><smiles>CC(O)(O)c1ccccc1</smiles><smiles>CC(=O)c1ccccc1</smiles><smiles>CCCCc1ccccc1</smiles><smiles>COC(O)c1ccccc1</smiles><smiles>O=Cc1ccccc1</smiles>

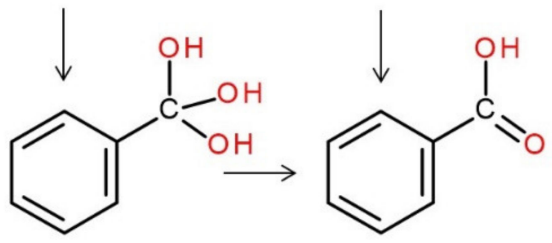

Figure 6. UPO-catalyzed, stepwise oxidation of benzylic carbon by the examples of ethylbenzene (above) and toluene (below), resulting in the formation of acetophenone and benzoic acid, respectively. The oxygen originating from peroxide $\left(\mathrm{H}_{2} \mathrm{O}_{2}\right)$ is marked in red.

In the case of less reactive alkanes, most UPOs favor the hydroxylation at secondary and tertiary (as far as sterically possible, e.g., in isobutane) carbons over that of terminal carbons, which is due to different $\mathrm{C}-\mathrm{H}$ bond dissociation energies $[11,103]$. Thus, linear alkanes (propane to $n$-hexadecane) are preferably oxidized to form alcohols with the hydroxyl group in the 2- or 3-position. Notably, MroUPO was found to oxygenate the unfavored terminal carbon of long-chain $n$-alkanes $\left(\mathrm{C}_{12}-\mathrm{C}_{14}\right)$ when ten-times-higher concentrations of $\mathrm{H}_{2} \mathrm{O}_{2}$ were applied. This led to mixtures of alcohols, ketones, and acids, including biotechnologically relevant dicarboxylic acids [62]. AaeUPO was also found to hydroxylate various cycloalkanes from cyclopentane to cyclooctane, yielding mainly the corresponding cycloalkanols and smaller amounts of cyclic ketones [103,104].

In fatty acids, representing amphiphilic alkyls, the rather 'unpolar' positions $\omega-1$ and $\omega-2$ are favored by AaeUPO [12]. In contrast, Olmedo et al. (2017) [62] demonstrated that MroUPO catalyzes the attack of the $\mathrm{C}_{\alpha}$ directly adjacent to the polar carboxylic group, which results in the shortening of fatty acids. This interesting reaction sequence (Figure 7) requires the incipient oxygenation of the fatty acids' $C_{\alpha}$ position, which, after a second hydroxylation, forms a gem-diol, being in equilibrium with the corresponding $\alpha$-keto fatty acid. Finally, a spontaneous, probably peroxide-forced oxidation yields the $\mathrm{C}_{1}$-shortened fatty acid (a decarboxylation that results in $\mathrm{CO}_{2}$ and a new $\mathrm{COOH}$ group). In analogy to 
the well-known $\beta$-oxidation, this pathway could be referred to as $\alpha$-oxidation of fatty acids. Similar consecutive peroxygenations and spontaneous oxidations have been reported for the deacylation (side chain removal) of corticosteroids [35].

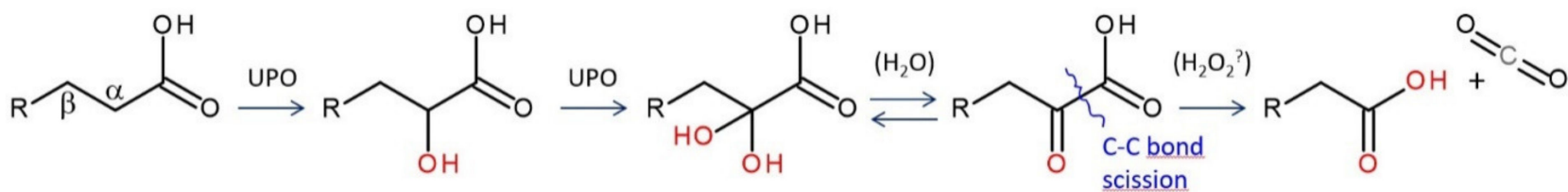

Figure 7. Shortening of fatty acids by stepwise oxidation of the $\mathrm{C}_{\alpha}$ carbon, resulting in the formation of an $\alpha$-keto derivative that spontaneously shortens via decarboxylation. The question mark at $\mathrm{H}_{2} \mathrm{O}_{2}$ indicates that it is unclear to what extent it contributes to final C-C scission.

The scission of ethers (O-dealkylation) is another UPO-catalyzed reaction sequence that starts with carbon oxygenation, namely of the ether bond's adjacent methylene $\left(\mathrm{R}-\mathrm{O}-\mathrm{CH}_{2}-\mathrm{R}^{\prime}\right)$ or methyl $\left(\mathrm{R}-\mathrm{O}-\mathrm{CH}_{3}\right)$ groups. We first demonstrated this reaction type using AaeUPO and a representative selection of substrates, including linear, branched, and cyclic ethers (e.g., diethyl ether, diisopropyl ether, tetrahydrofuran, 1,4-dimethoxybenzene) [89]. Upon hydroxylation, a hemiacetal is formed (e.g., $\mathrm{R}_{1}-\mathrm{O}-\mathrm{CH}_{2}-\mathrm{OH}-\mathrm{R}_{2}$ ) that spontaneously cleaves (actually, the hemiacetal is in equilibrium with the corresponding alcohol and aldehyde, similar to carbonyl hydrates (gem-diols) with water and free carbonyls) into an alcohol $\left(\mathrm{R}_{1}-\mathrm{OH}\right)$ and an aldehyde $\left(\mathrm{O}=\mathrm{CH}_{2}-\mathrm{R}_{2}\right)$, in which the alcohol bears the oxygen of the original ether and the carbonyl that of UPO-catalyzed oxygenation (Figure 8).<smiles>[R]OC([R2])([R])[2H]</smiles><smiles>[R]OC([R])([R])O</smiles><smiles>[R]O[14CH2]O</smiles><smiles>[R]C([R])=O</smiles>

Figure 8. Ether scission (O-dealkylation) via a hemiacetal intermediate, resulting in the formation of an alcohol and a carbonyl $\left(R_{2}\right.$ and $R_{3}=$ organic rests $\rightarrow$ ketone, $R_{2}$ or $R_{3}=H \rightarrow$ aldehyde).

The oxidative fission of an ester, as a special case of $O$-dealkylation, was observed only for one UPO from the ink-cap Coprinellus radians (CraUPO), which cleaved the antiviral drug osaltemivir in an $\mathrm{H}_{2} \mathrm{O}_{2}$-dependent manner [85]. Analogously to $\mathrm{O}$-dealkylations, UPOs catalyze also $\mathrm{N}$-dealkylations, with hemiaminals as putative intermediates. This was demonstrated for some alkylated anilines and various human drugs, including bulky pharmaceuticals such as SAR548304 (volixibat) [85,88,105].

Benzene, as the prototypical arene molecule, may serve as an example for the attack of the relatively stable aromatic ring. AaeUPO was found to oxygenate this non-activated $\mathrm{sp}^{2}$ system substantially [106]. Phenol (hydroxybenzene), catechol (1,2-dihydroxybenzene), and hydroquinone (1,4-dihydroxybenzene) were the major products of this reaction (additionally, traces of trihydroxybenzenes can be formed) (Figure 9). Long UPOs such as AaeUPO (and, to some extent, CraUPO) may even favor this reaction over side-chain oxidation (as in the case of toluene, stelbenoids, and several pharmaceuticals), while short UPOs (e.g., MroUPO) hardly oxidize the benzene ring or related structures [107]. It can be assumed that all 'aromatic hydroxylations' proceed via an initial epoxidation to the corresponding arene oxide (epoxyarene), though this was explicitly demonstrated only for benzene and naphthalene as substrates and AaeUPO as an enzyme [106,108]. In the case of benzene, the epoxyarene is in equilibrium with the corresponding oxepine and, due to the force of aromatization, the spontaneous isomerization of the epoxide follows epoxidation, giving rise to the corresponding phenols. This type of oxyfunctionalization was also shown for various substituted monoaromatic compounds and polycyclic aromatic hydrocarbons up to benzo(a)pyrene $[49,85,86,109]$. 


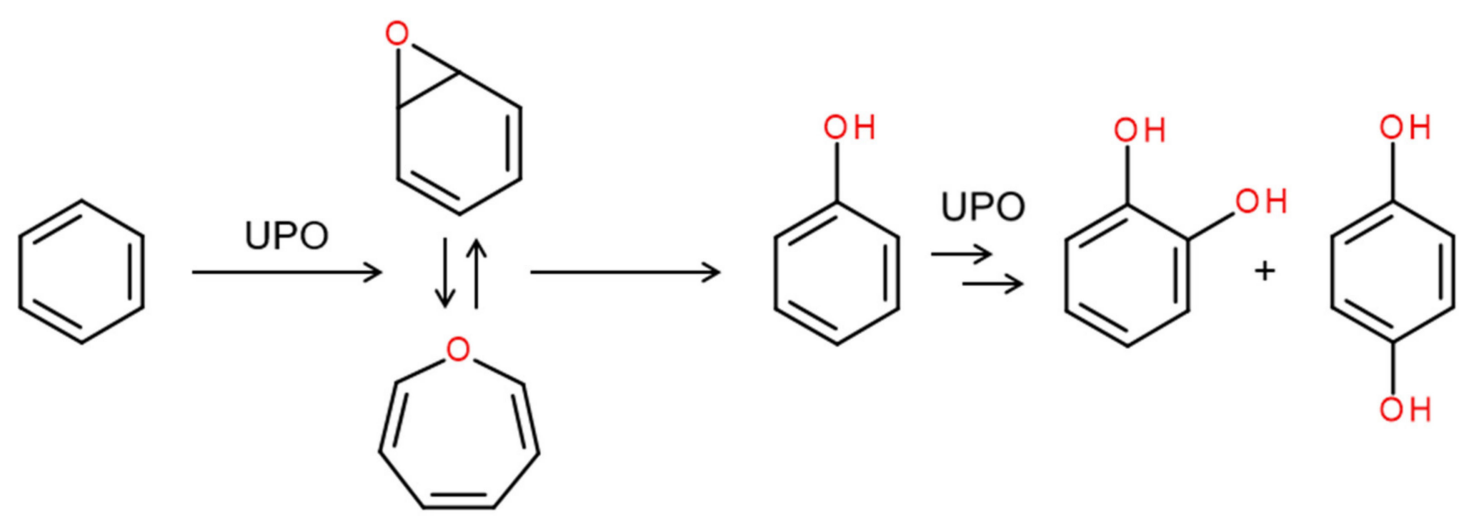

Figure 9. Epoxidation of benzene and subsequent spontaneous isomerization of benzene oxide under re-aromatization to form phenol. The second attack gives catechol and hydroquinone (modified according to [106]). The reaction sequence was confirmed using ${ }^{18} \mathrm{O}$-enriched hydrogen peroxide $\left(\mathrm{H}_{2}{ }^{18} \mathrm{O}_{2}\right)$ as a co-substrate. Note, both benzene oxide and oxepine were detectable by HPLC.

The oxygenation of aliphatic and alicyclic alkenes (e.g., propene, trans-butene, cyclohexene) follows a similar scheme, resulting in respective epoxides (oxiranes) (Figure 10). However, due to a lacking driving force, the rearrangement of these epoxides is not promoted and they remain relatively stable [110]. Epoxidation of aliphatic $\mathrm{sp}^{2}$ carbons is catalyzed by all available UPOs (including CPO) and functions with a broad range of substrates, from simple and branched alkenes, via unsaturated fatty acids, to cyclic alkenes including complex terpenes and steroids [38,111-115].

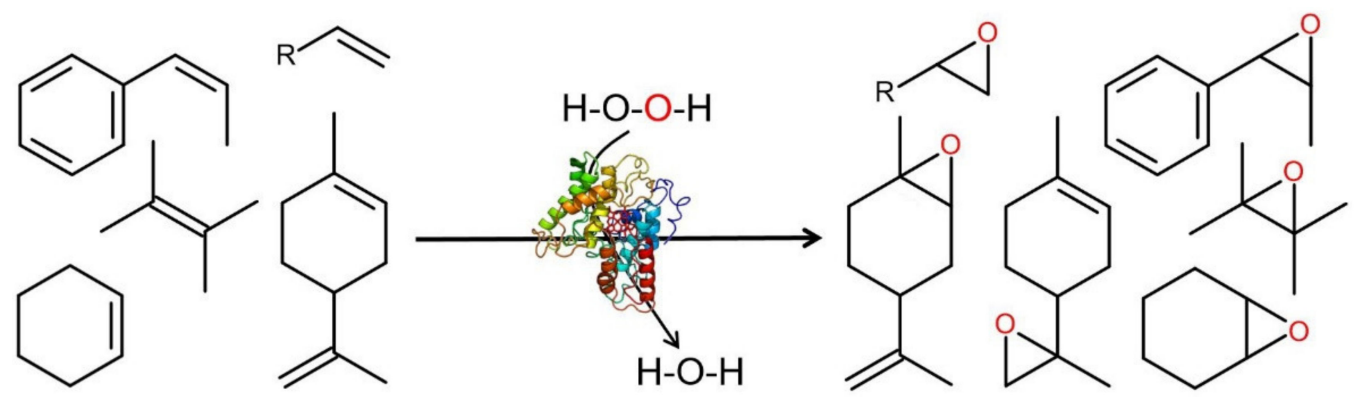

Figure 10. Epoxidation of aliphatic and cycloaliphatic alkenes (attack on $\mathrm{sp}^{2}$ carbons). Left side: (cis-methylstyrene, 1-alkene ( $\left.\mathrm{R}=\mathrm{C}_{1}-\mathrm{C}_{6}\right)$, cyclohexene, limonene; right side: 1,2-alkene oxide (2-alkyloxirane), cis-methylstyrene oxide (2-methyl-3-phenyloxiranre), limonene 6,7-oxide (4isopropenyl-1-methoxy-1-methyl-cyclohexene), limonene 2,9-oxide [4-(2-methoxy-1-methyl-ethyl)-1methyl-cyclohexene], (2,2,3,3-tetramethyloxirane), cyclohexene oxide (7-oxabicyclo[4.1.0]heptane).

In addition to the oxygenation of carbon atoms (C), UPOs were shown to oxygenate organic heteroatoms such as sulfur $(S)$ and nitrogen $(\mathrm{N})$ (Figure 11). In the latter case, they favor $N$-dealkylation over $N$-oxidation, if the nitrogen is substituted with alkyls (e.g., methyl group). In contrast, aromatic nitrogen as found in pyridine is subject to $N$-oxidation [116]. Pyridine and its derivatives are relatively electron-deficient and thus inactivated regarding electrophilic attack. Hence, it is plausible that the yields of pyridine $\mathrm{N}$-oxides are rather poor in UPO conversions. The formation of phenolic products (i.e., pyridinoles = hydroxypyridines) has never been observed. It is assumed that the heterocyclic nitrogen tends to coordinate towards the heme iron so that its oxidation is favored over that of carbons. There is also an indication that AaeUPO can attack the amino group in anilines via $\mathrm{N}$-oxidation, resulting in the corresponding hydroxylamino derivatives; however, the major products of aniline oxidation are aminophenols $[117,118]$. 

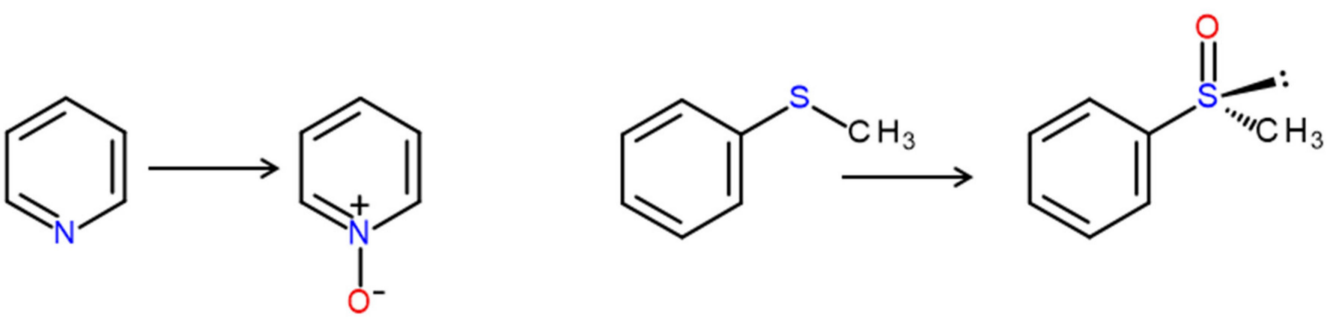

Figure 11. Oxygenation of pyridine's heterocyclic nitrogen (left reaction) and of thioanisole (right), resulting in the formation of pyridine $N$-oxide and $(R)$-phenyl methyl sulfoxide $[(R)$ methylsulfinylbenzene], respectively.

AaeUPO catalyzes also sulfoxidations, which were thoroughly studied by the example of thioanisole and related aryl-alkyl sulfides that were also oxidized in deep eutectic solvents $[119,120]$. In all cases, the absolute configuration of the resulting sulfoxides was $(R)$ and the enantiomeric excess reached up to $>99 \%$ in dependence on the alkyl substituent and the reaction conditions. Besides aryl-alkyl model sulfides, sulfoxidations were also reported for complex molecule such as the pharmaceutical omeprazole and the crude oil constituent dibenzothiophene $[85,121]$.

UPOs (e.g., AaeUPO, CraUPO, rCciUPO) chlorinate organic compounds only poorly (in contrast to their 'sister enzyme' chloroperoxidase), but most of them show brominating activities for phenolic substrates [36,41,122]. Notably, MroUPO was found to neither chlorinate nor brominate phenolic substrates [34]. The most plausible reaction mechanism includes the formation of reactive hypohalites $\left(\mathrm{OX}^{-}\right)$as primary oxygenation products that in turn attack preferably sp ${ }^{2}$-hybridized carbons $[10,123]$.

$$
\text { (i) } \mathrm{X}^{-}+\mathrm{H}_{2} \mathrm{O}_{2} \rightarrow \mathrm{OX}^{-}+\mathrm{H}_{2} \mathrm{O} \text { (ii) } \mathrm{OX}^{-}+\mathrm{R}-\mathrm{H} \rightarrow \mathrm{HX}+\mathrm{R}-\mathrm{X} \mathrm{R}=\text { phenyl, } \mathrm{X}=\mathrm{Br},(\mathrm{Cl})
$$

There is high variation in the halogenating activities of UPOs, but the molecular basics that guide these reactions, particularly regarding their selectivity, are not fully understood.

More than a decade of intensive studies on the reactions of UPOs, of course, also revealed several limitations in the general performance of these enzymes. The most important constraints are: (a) steric hindrance and too large substrates, (b) the absence of abstractable hydrogen atoms at the carbon(s) to be attacked, and (c) too high C-H bond dissociation energies (BDEs). Steric constraints that limit the substrate spectrum of UPOs to smaller substrates are not surprising, since the actual oxygenation requires the direct contact of at least part of the substrate with the ferryl oxygen $\left(\mathrm{Fe}^{4+}=\mathrm{O}\right)$ of the activated heme, UPO Cpd-I, which requires their passage through the heme access channel. Thus, larger and compact molecules such as perylene (5-ring $\left.\mathrm{PAH}, \mathrm{C}_{20} \mathrm{H}_{12}\right)$ and cyclodecane $\left(\mathrm{C}_{10} \mathrm{H}_{20}\right)$ were oxidized neither by AaeUPO nor by CraUPO $[109,112]$. The same applies to polymeric lignin, although a non-phenolic lignin dimer was oxidized by AaeUPO [117,124]. Whether UPOs with rather wide and shallow heme access channels exist (or can be engineered), which allow heme to contact bulky polymeric substrates such as lignin (analogous to the interaction of the copper centers of lytic polysaccharide monooxygenases (LPMOs) with crystalline cellulose) [125], will be an intriguing question for the future. Furthermore, biphenyl ethers cannot undergo ether scission because of the absence of hydrogens at the ether oxygen's adjacent carbons. Moreover, 2,2,3,3-tetramethylbutane is a further example of a molecule that cannot be attacked by UPOs due to the lack of abstractable hydrogens. The molecule contains six terminal carbons that cannot be oxidized because of the high C-H BDEs, and two carbons (at positions 2 and 3) that do not bear any hydrogen [112]. Eventually, methane, with its exceptionally high C-H BDE $\left(105 \mathrm{kcal} \mathrm{mol}^{-1}\right)$, was not converted by AaeUPO [112], which is in accordance with the BDE vs. log k plot for AaeUPO Cpd-I [11].

Despite these obvious limitations, we anticipate that new UPO-catalyzed reactions will be found in the coming years, particularly if the large-scale production of diverse recombinant UPOs succeeds. One example from our current research is the cleavage of activated aromatic rings as found in catechol, which mimics a dioxygenase-type reaction. 


\section{Occurrence in the Fungal Kingdom and Phylogeny}

We have meanwhile found several thousand putative UPO sequences in databases and fungal genomes, more than 4000 alone in NCBI, corresponding to more than 8000 in JGI Mycocosm (i.e., out of 2156 genome-sequenced fungi, UPOs are present in 1656 fungi; blast search from November 2021) and several hundred from our own unpublished genome sequencing approaches [72]. This suggests the wide distribution of these enzymes throughout the fungal kingdom, which includes all phyla of true fungi (Eumycota) as well as a number of fungus-like Stramenopiles [2,29]. Within the most basal sister group of all other fungi, the Cryptomycota, one UPO gene was identified in Rozella allomycis, an obligate endoparasite in other primordial fungi and fungus-like protists [126]. Notably, other basal fungal groups (Microsporidia, Neocallimastigomycota, Blastocladiomycota, Kickxellomycotina) lack UPO genes (according to the genomes available so far); the same is true for the sister group of fungi, the Holozoa, which includes animals (Metazoa) and their closest relatives (Choanoflagellata, Ichthyosporea). Representatives of the Chytridiomycota ('flagellate fungi'), on the other hand, possess up to seven UPO genes. Thus, their enzymes may have been the starting point for the evolutionary development of the UPO multigene family, which eventually led to the possession of 80 or more UPO genes in an individual species of 'higher fungi' [29]. Apart from the Mortierellomycotina, sequenced representatives of the other groups of the polyphyletic 'Zygomycota' and Glomeromycota possess one to seven UPO genes.

Within the species-rich subkingdom of 'higher fungi' (Dikarya, i.e., Ascomycota and Basidiomycota), UPO genes are particularly abundant. They reach their greatest number within the Ascomycota in the citrus pathogen Zasmidium citri-griseum (up to 33 genes) and in the halotolerant black yeast Hortaea werneckii (up to 25 genes) [29]. Within the Basidiomycota, species from different eco-physiological fungal groups have multiple UPO genes, especially common among decomposers of soil leaf litter, compost, and dung. For example, the 'Cannon ball fungus' (Sphaerobolus stellatus), which grows on woody debris and manure, possesses no fewer than 78 UPO genes. The record holder, for the time being (12/2021), is Mycena rebaudengoi (leaf litter and twig decomposer), with no less than 83 UPO genes. In our own, yet unpublished, studies, we have found over 60 UPO genes in the 'Pinwheel mushroom' (Marasmius rotula) and 48 genes in the newly described Kenyan species Candolleomyces (Psathyrella) aberdarensis [2,29]; both fungi preferentially colonize small woody debris as well. The most important commercial edible fungus, the 'White button mushroom' (Agaricus bisporus), which is routinely grown on nitrogen-rich compost materials, is also rich in UPOs (24 genes) [127,128]. Putative UPO genes outside of the true fungi (Eumycota) have only been found in various Peronosporomycetes (formerly 'Oomycota'), two diatoms, and in one slime-mold-like organism (Planoprotostelium fungivorum). In the latter two cases, the assignment is uncertain and must be confirmed by additional genomes of related species in the Bacillariophyta (SAR, Stramenopiles-Alveolata-Rhizaria supergroup) and Amoebozoa (sister supergroup of Eumycota and Metazoa/animals). Peronosporomycetes are fungus-like Stramenopiles that are phylogenetically closer to colored algae (e.g., Phaeophyta) than to true fungi. Corresponding UPO genes have been detected, among others, in the pathogens Aphanomyces astaci (crayfish plague) and Phytophthora infestans (potato blight, eleven UPO genes). There is evidence that these pseudo-fungi, also known as 'water molds' (having up to 24 UPO genes as in a Neophytophtora sp.), obtained them multiple times via horizontal gene transfer from pathogenic Ascomycota $[129,130]$. As another phylogenetic trend, we have found that certain yeasts and yeast-like fungi with reduced genomes within the Ascomycota and Basidiomycota lack UPO genes (Saccharomycotina, Schizosaccharomycetes, Malasseziamycetes).

Phylogenetically, UPO sequences can be divided into two protein families. Family I-the 'short' UPO sequences-includes representatives of all the above-mentioned UPO-containing phylogenetic groups of fungi (including Peronosporomycetes). Family II houses the 'long' UPOs, whose occurrence is restricted to the Dikarya, i.e., Ascomycota and Basidiomycota (Figure 12). Some distinct basal subgroups in family I contain UPO sequences without recognizable signal peptides or subcellular localization signals, so it 
seems plausible that the UPO archetype had been an intracellular enzyme. In total, this concerns approximately $30 \%$ of the analyzed UPO sequences (Figure 12). Whether these enzymes function freely in the cytosol, act in specific hyphal compartments, or are secreted by alternative pathways (e.g., exocytose vesicles) is unclear. The current UPO phylogeny using a distance and maximum-likelihood approach displays a finer branching than previous attempts [2,29]. The 'short' UPOs seem to diversify into several subfamilies, some without a signal peptide, hereby including all basal fungal taxa (Figure 12).

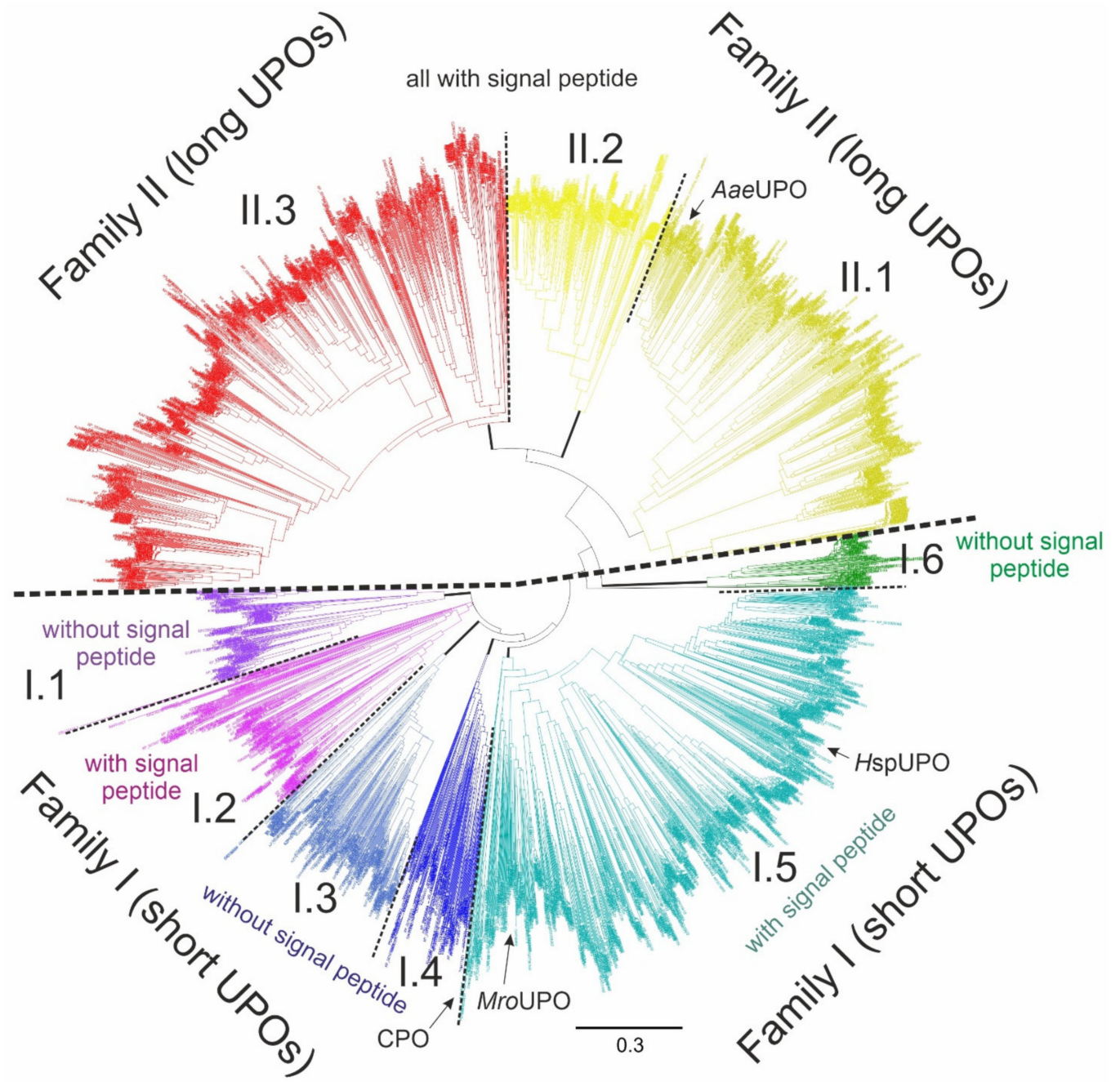

Figure 12. Neighbor-joining phylogenetic tree of 3728 UPO/HTP sequences using genetic distances calculated with Geneious Prime 2021. Classification into short and long UPOs (families I and II, respectively) as well as into clearly distinguishable clades (subfamilies I.1-I.6 and II.1-II.3) is illustrated by different colors and black dashed lines. UPO sequences with resolved crystal structure are marked with arrows (AaeUPO—Cyclocybe aegerita PDB: 2YOR, HspUPO—Hypoxylon sp. EC38 PDB: 7O2G, MroUPO-Marasmius rotula PDB: 5FUK, CPO_Leptoxyphium (Caldariomyces) fumago PDB: 1CPO). UPO genes of indicated thick branches are composed identically using a maximum-likelihood approach (FastTree 2.1.11 [131], 20 rate categories). Clades of putatively secreted UPOs carrying signal peptides and probably intracellular UPOs without such sequences are labeled with appropriate text. The nine distinguishable clades comprise fungal UPO genes of different taxonomic affiliation (on phyla and subphyla levels): clade I.1-Ascomycota, Cryptomycota; clade I.2-Ascomycota, Basidiomycota, Chytridiomycota, Mucoromycotina, Oomycetes, Zoopagomycota; clade I.3-Ascomycota, Basidiomycota; clade I.4-Basidiomycota; clade I.5-Ascomycota, Basidiomycota; clade I.6-Ascomycota; clade II.1Ascomycota, Basidiomycota; clade II.2-Ascomycota, Basidiomycota; clade II.3-Ascomycota, Basidiomycota. 
Since UPOs are found exclusively in the fungal kingdom [132], including the basal Cryptomycota, and no evidence for their presence in the Holozoa has yet been found, it can be postulated that they originated more than 600 million years ago (late Proterozoic), after the splitting of Opisthokonta into their major groups (Eumycota and Holozoa/Metazoa). It seems plausible that the drastic conditions of the second evolving $\mathrm{O}_{2}$ atmosphere during this time (around 700-550 million years ago) played an evolutionary role in this process, similar to the case of P450 enzymes. Whether UPOs and P450s have a common origin is still unclear, but, if so, it might date back to more than a billion years ago (before the separation of the major eukaryote lineages) [133]. Although both enzyme types share structural and catalytic similarities (cysteine as proximal heme ligand, reactive heme intermediates, i.e., compounds 0 , I, II), there is almost no homology $(<5 \%)$ at the sequence level and hardly any similarity in the tertiary protein structure (arrangement of $\alpha$-helices) [134], which rather points to the convergent evolutionary development of UPOs and P450s under similar environmental pressure $[8,135]$. In fungal organisms where both enzyme types occur, it may plausible that there is a division of labor between P450 enzymes and peroxygenases, in which one works inside hyphae and the other outside.

\section{Conclusions and Outlook}

Despite their high relevance for synthetic applications in (bio)organic chemistry, only a few UPOs are available so far and none of them in economically relevant amounts. Furthermore, almost nothing is known about their natural functions, which is not merely an academic question but also important regarding biotechnological attempts and ecophysiological considerations. Taking into account their wide distribution in the fungal kingdom, their high number in the genomes of certain fungi, and their promiscuity in terms of catalyzed reactions, different functions are conceivable. The first would certainly be detoxification reactions, as UPOs attack structures commonly found in plant and microbial secondary metabolites and pharmaceuticals, as well as environmental pollutants $[7,8,136]$. Bearing in mind the high diversity of UPO genes, involvement in pathogenicity events or in lignin and humus transformation should also not be excluded. For the latter, a molecular architecture would be required that allows the superficial targeting of aromatic polymer structures via heme access channels that are as broad and shallow as possible. In this context, it should be noted that, according to recent publications, the crystalline cellulose-cleaving LPMOs (lytic polysaccharide monooxygenases), which were discovered only a few years ago, are also surface-acting extracellular peroxygenases (albeit based on copper-dependent catalysis) [125,137,138].

Modern molecular techniques such as genome editing using CRISPR/Cas could help to answer the question regarding the function of UPOs. For this, UPO knock-out mutants of suitable model organisms would need to be generated and subsequently physiologically tested. Molecular and enzymatic field studies (e.g., in the context of the Biodiversity Exploratories, DFG SPP-1374) could also help to clarify the functions of UPOs-for example, in a manner similar to that achieved in the case of manganese peroxidases $[139,140]$. In order to accelerate the production of recombinant UPOs, cell-free expression with isolated ribosomes could be an innovative approach, in addition to the further development of all types of microbial and other expression systems (yeasts, molds, bacteria, plant and insect cells, etc.).

Author Contributions: Conceptualization, M.H., R.U., H.K., R.H.; methodology, A.K., J.K., H.K., R.H, R.U.; software, H.K., R.H., R.U.; validation, M.H., K.S.; formal analysis, M.H., R.U., H.K.; investigation, R.U., A.K., R.H., J.K.; resources, M.H., K.S.; data curation, R.U., H.K., R.H., A.K., J.K.; writingoriginal draft preparation, M.H.; writing-review and editing, M.H., R.U.; visualization, R.U., M.H., H.K., R.H.; supervision, M.H.; project administration, M.H., R.U., K.S.; funding acquisition, K.S., M.H. All authors have read and agreed to the published version of the manuscript. 
Funding: This research was funded by the German Ministry of Research (BMBF; latest projects CEFOX 031B0831 and JaBaS 031B118), the Fraunhofer Gesellschaft (project PZ-Syn 22-F241-03-FhG/005/001), the European Union (EU, latest project SusBind H2020-BBI-JTI-2017), and the Deutsche Forschungsgemeinschaft (DFG, joint BELOngDead projects within SPP 1374).

Acknowledgments: The authors would like to thank the administration of IHI Zittau and TU Dresden, as well as the lab engineers, technicians, and students of the IHI Zittau.

Conflicts of Interest: The authors declare no conflict of interest.

\section{References}

1. Schomburg, D.; Schomburg, I. Class 1 Oxidoreductases EC 1, 2nd ed.; Springer: Berlin/Heidelberg, Germany, 2013 ; pp. 504-516.

2. Hofrichter, M.; Kellner, H.; Pecyna, M.J.; Ullrich, R. Fungal unspecific peroxygenases: Heme-thiolate proteins that combine peroxidase and cytochrome P450 properties. In Monooxygenase, Peroxidase and Peroxygenase Properties and Mechanisms of Cytochrome P450; Hrycay, E.G., Bandiera, S.M., Eds.; Springer International Publishing: Cham, Switzerland, 2015; pp. 341-368.

3. Ramirez-Escudero, M.; Molina-Espeja, P.; Gomez de Santos, P.; Hofrichter, M.; Sanz-Aparicio, J.; Alcalde, M. Structural insights into the substrate promiscuity of a laboratory-evolved peroxygenase. ACS Chem. Biol. 2018, 13, 3259-3268. [CrossRef] [PubMed]

4. Münch, J.; Püllmann, P.; Zhang, W.; Weissenborn, M.J. Enzymatic hydroxylations of sp ${ }^{3}$-carbons. ACS Catal. 2021, 11, 9168-9203. [CrossRef]

5. $\quad$ Ullrich, R.; Nüske, J.; Scheibner, K.; Spantzel, J.; Hofrichter, M. Novel haloperoxidase from the agaric basidiomycete Agrocybe aegerita oxidizes aryl alcohols and aldehydes. Appl. Environ. Microbiol. 2004, 70, 4575-4581. [CrossRef] [PubMed]

6. Matheny, P.B.; Curtis, J.M.; Hofstetter, V.; Aime, M.C.; Moncalvo, J.-M.; Ge, Z.-W.; Yang, Z.-L.; Slot, J.C.; Ammirati, J.F.; Baroni, T.J.; et al. Major clades of Agaricales: A multilocus phylogenetic overview. Mycologia 2006, 98, 982-995. [CrossRef]

7. Kiebist, J.; Hofrichter, M.; Zuhse, R.; Scheibner, K. Oxyfunctionalization of pharmaceuticals by fungal peroxygenases. In Pharmaceutical Biocatalysis: Chemoenzymatic Synthesis of Active Pharmaceutical Ingredients; Grunwald, P., Grunwald, P., Eds.; Pan Stanford Series on Biocatalysis; Jenny Stanford Publishing: Singapore, 2019; Volume 5.

8. Ullrich, R.; Karich, A.; Hofrichter, M. Fungal peroxygenases-A versatile tool for biocatalysis. In Encyclopedia of Mycology; Zaragoza, Ó., Casadevall, A., Eds.; Elsevier: Oxford, UK, 2021; pp. 260-280.

9. Manoj, K.M.; Hager, L.P. Chloroperoxidase, a Janus enzyme. Biochemistry 2008, 47, 2997-3003. [CrossRef]

10. Hofrichter, M.; Ullrich, R. Heme-thiolate haloperoxidases: Versatile biocatalysts with biotechnological and environmental significance. Appl. Microbiol. Biotechnol. 2006, 71, 276-288. [CrossRef]

11. Wang, X.; Peter, S.; Kinne, M.; Hofrichter, M.; Groves, J.T. Detection and kinetic characterization of a highly reactive heme-thiolate peroxygenase compound I. J. Am. Chem. Soc. 2012, 134, 12897-12900. [CrossRef]

12. Babot, E.D.; del Río, J.C.; Kalum, L.; Martínez, A.T.; Gutiérrez, A. Oxyfunctionalization of aliphatic compounds by a recombinant peroxygenase from Coprinopsis cinerea. Biotechnol. Bioeng. 2013, 110, 2323-2332. [CrossRef]

13. Martínez, A.T.; Ruiz-Dueñas, F.J.; Camarero, S.; Serrano, A.; Linde, D.; Lund, H.; Vind, J.; Tovborg, M.; Herold-Majumdar, O.M.; Hofrichter, M.; et al. Oxidoreductases on their way to industrial biotransformations. Biotechnol. Adv. 2017, 35, 815-831. [CrossRef]

14. Molina-Espeja, P.; de Santos, P.G.; Alcalde, M. Directed evolution of unspecific peroxygenase. In Directed Enzyme Evolution: Advances and Applications; Alcalde, M., Ed.; Springer International Publishing: Cham, Switzerland, 2017; pp. 127-143.

15. Ullrich, R.; Poraj-Kobielska, M.; Herold-Majumdar, O.M.; Vind, J.; Hofrichter, M. Synthesis of indigo-dyes from indole derivatives by unspecific peroxygenases and their application for in-situ dyeing. Catalysts 2021, 11, 1495. [CrossRef]

16. Hofrichter, M.; Scheibner, K.; Nüske, J.; Ullrich, R. Enzymatic Production of Acids with Intermediate Formation of Aldehydes in a Single Stage Reaction from Alcohols, Involves Addition of Fresh Arylalcohol-Arylaldehyde-Peroxidases and an Oxidant. German Patent DE10332065A1, 11 July 2003.

17. Hofrichter, M.; Scheibner, K.; Ullrich, R.; Kinne, M.; Peter, S.; Lund, H.; Kalum, L. Regioselective Hydroxylation of Aliphatic Hydrocarbons Employing a Fungal Peroxygenase. EU Patent EP2553109B1, 28 May 2010.

18. Lund, H.; Kalum, L.; Hofrichter, M.; Peter, S. Epoxidation Using Peroxygenase. Patents PCT/EP2013/056326, US9663806, U9908860B2, US10358429B2, 31 May 2012.

19. Pecyna, M.; Schnorr, K.M.; Ullrich, R.; Scheibner, K.; Kluge, M.; Hofrichter, M. Fungal Peroxygenases and Methods of Application. Patent WO 2008/119780 A2, 30 May 2007.

20. Landvik, S.; Oestergaard, L.H.; Kalum, L. Poplypeptides Having Peroxygenase Activity and Polynucleotides Encoding Same. U.S. Patent 14,361,390, 2 December 2011.

21. Molina-Espeja, P.; Plougasca, F.J.; Alcalde, M.; Gomez de Santos, P. Nonspecific Peroxygenase Mutants with High Monooxygenase Activity and Their Uses. Patents WO 2017/081355 A1, PCT/ES2016/070809, 13 November 2015.

22. Fernández-Fueyo, E.; Aranda, C.; Gutiérrez, A.; Martínez, A.T. Method of Heterologous Expression of Active Fungal Unspecific Peroxygenase in Bacterial Host Cells for Fatty-Acid Epoxidation and Other Oxygenation Reactions. Patents WO 2020/011847 A1, PCT/EP2019/068519, 10 July 2018.

23. Schramm, M.; Schmidtke, K.-U.; Scheibner, K. Process for the Cell-Free Preparation of Non-Specific Peroxygenases and Their Use. German Patent DE 102021209 758.8, 3 September 2021. 
24. Hofrichter, M.; Ullrich, R.; Pecyna, M.; Liers, C.; Lundell, T. New and classic families of secreted fungal heme peroxidases. Appl. Microbiol. Biotechnol. 2010, 87, 871-897. [CrossRef]

25. Hofrichter, M.; Ullrich, R. Oxidations catalyzed by fungal peroxygenases. Curr. Opin. Chem. Biol. 2014, 19, 116-125. [CrossRef]

26. Püllmann, P.; Weissenborn, M.J. Pilzliche Peroxygenasen: Der Schlüssel zu C-H-Hydroxylierungen und mehr? BIOspektrum 2019, 25, 572-574. [CrossRef]

27. Sigmund, M.-C.; Poelarends, G.J. Current state and future perspectives of engineered and artificial peroxygenases for the oxyfunctionalization of organic molecules. Nat. Catal. 2020, 3, 690-702. [CrossRef]

28. Scheibner, K.; Ullrich, R.; Kiebist, J.; Kellner, H.; Hofrichter, M. Unspezifische Peroxygenasen-Oxyfunktionalisierung außerhalb der Pilzhyphe. BIOspektrum 2020, 26, 103-106. [CrossRef]

29. Hofrichter, M.; Kellner, H.; Herzog, R.; Karich, A.; Liers, C.; Scheibner, K.; Kimani, V.W.; Ullrich, R. Fungal Peroxygenases: A Phylogenetically Old Superfamily of Heme Enzymes with Promiscuity for Oxygen Transfer Reactions. In Grand Challenges in Fungal Biotechnology; Grand Challenges in Biology and Biotechnology; Nevalainen, H., Rampelotto, P.H., Eds.; Springer Nature: Cham, Switzerland, 2020; Volume 1, pp. 369-403.

30. Mahor, D.; Cong, Z.; Weissenborn, M.J.; Hollmann, F.; Zhang, W. Valorization of small alkanes by biocatalytic oxyfunctionalization. ChemSusChem 2021, 14, 1-12. [CrossRef]

31. Hobisch, M.; Holtmann, D.; Gomez de Santos, P.; Alcalde, M.; Hollmann, F.; Kara, S. Recent developments in the use of peroxygenases-Exploring their high potential in selective oxyfunctionalisations. Biotechnol. Adv. 2021, 51, 107615. [CrossRef]

32. Ullrich, R.; Liers, C.; Schimpke, S.; Hofrichter, M. Purification of homogeneous forms of fungal peroxygenase. Biotechnol. J. 2009, 4, 1619-1626. [CrossRef]

33. Gupta, D.K.; Rühl, M.; Mishra, B.; Kleofas, V.; Hofrichter, M.; Herzog, R.; Pecyna, M.J.; Sharma, R.; Kellner, H.; Hennicke, F.; et al The genome sequence of the commercially cultivated mushroom Agrocybe aegerita reveals a conserved repertoire of fruiting-related genes and a versatile suite of biopolymer-degrading enzymes. BMC Genom. 2018, 19, 48. [CrossRef]

34. Gröbe, G.; Ullrich, R.; Pecyna, M.J.; Kapturska, D.; Friedrich, S.; Hofrichter, M.; Scheibner, K. High-yield production of aromatic peroxygenase by the agaric fungus Marasmius rotula. AMB Express 2011, 1, 31. [CrossRef]

35. Ullrich, R.; Poraj-Kobielska, M.; Scholze, S.; Halbout, C.; Sandvoss, M.; Pecyna, M.J.; Scheibner, K.; Hofrichter, M. Side chain removal from corticosteroids by unspecific peroxygenase. J. Inorg. Biochem. 2018, 183, 84-93. [CrossRef]

36. Anh, D.H.; Ullrich, R.; Benndorf, D.; Svatoś, A.; Muck, A.; Hofrichter, M. The coprophilous mushroom Coprinus radians secretes a haloperoxidase that catalyzes aromatic peroxygenation. Appl. Environ. Microbiol. 2007, 73, 5477-5485. [CrossRef]

37. Melzer, A.; Kimani, V.W.; Ullrich, R. Psathyrella aberdarensis, a new species of Psathyrella (Agaricales) from a Kenyan National Park. Austrian J. Mycol. 2018, 27, 23-30.

38. Kiebist, J.; Schmidtke, K.-U.; Zimmermann, J.; Kellner, H.; Jehmlich, N.; Ullrich, R.; Zänder, D.; Hofrichter, M.; Scheibner, K. A peroxygenase from Chaetomium globosum catalyzes the selective oxygenation of testosterone. ChemBioChem 2017, 18, 563-569. [CrossRef] [PubMed]

39. Pecyna, M.; Ullrich, R.; Bittner, B.; Clemens, A.; Scheibner, K.; Schubert, R.; Hofrichter, M. Molecular characterization of aromatic peroxygenase from Agrocybe aegerita. Appl. Microbiol. Biotechnol. 2009, 84, 885-897. [CrossRef] [PubMed]

40. Piontek, K.; Strittmatter, E.; Ullrich, R.; Gröbe, G.; Pecyna, M.J.; Kluge, M.; Scheibner, K.; Hofrichter, M.; Plattner, D.A. Structural basis of substrate conversion in a new aromatic peroxygenase: Cytochrome P450 functionalities with benefits. J. Biol. Chem. 2013, 288, 34767-34776. [CrossRef] [PubMed]

41. Anh, D.H. Novel Extracellular Haloperoxidase-Peroxygenases from the Coprophilous Fungi Coprinus radians and Coprinus verticillatus: Production, Purification and Biochemical Characterization. Ph.D. Thesis, International Graduate School of Zittau, Zittau, Germany, 2008.

42. Pecyna, M. Molecular Biological Charaterization of Heme-Thiolate and DyP-Type Peroxidases of Selected Basidiomycetes. Ph.D. Thesis, TU Dresden, Dresden, Germany, 2016.

43. Wang, X.W.; Yang, F.Y.; Meijer, M.; Kraak, B.; Sun, B.D.; Jiang, Y.L.; Wu, Y.M.; Bai, F.Y.; Seifert, K.A.; Crous, P.W.; et al. Redefining Humicola sensu stricto and related genera in the Chaetomiaceae. Stud. Mycol. 2019, 93, 65-153. [CrossRef]

44. Aranda, C.; Municoy, M.; Guallar, V.; Kiebist, J.; Scheibner, K.; Ullrich, R.; del Río, J.C.; Hofrichter, M.; Martínez, A.T.; Gutiérrez, A. Selective synthesis of 4-hydroxyisophorone and 4-ketoisophorone by fungal peroxygenases. Catal. Sci. Technol. 2019, 9, 1398-1405. [CrossRef]

45. Molina-Espeja, P.; Garcia-Ruiz, E.; Gonzalez-Perez, D.; Ullrich, R.; Hofrichter, M.; Alcalde, M. Directed evolution of unspecific peroxygenase from Agrocybe aegerita. Appl. Environ. Microbiol. 2014, 80, 3496-3507. [CrossRef]

46. Molina-Espeja, P.; Ma, S.; Mate, D.M.; Ludwig, R.; Alcalde, M. Tandem-yeast expression system for engineering and producing unspecific peroxygenase. Enzyme Microb. Technol. 2015, 73-74, 29-33. [CrossRef]

47. Molina-Espeja, P.; Cañellas, M.; Plou, F.J.; Hofrichter, M.; Lucas, F.; Guallar, V.; Alcalde, M. Synthesis of 1-naphthol by a natural peroxygenase engineered by directed evolution. ChemBioChem 2016, 17, 341-349. [CrossRef]

48. Mate, D.M.; Palomino, M.A.; Molina-Espeja, P.; Martin-Diaz, J.; Alcalde, M. Modification of the peroxygenative:peroxidative activity ratio in the unspecific peroxygenase from Agrocybe aegerita by structure-guided evolution. Prot. Eng. Des. Sel. 2017, 30, 191-198. [CrossRef] 
49. Kinne, M.; Poraj-Kobielska, M.; Aranda, E.; Ullrich, R.; Hammel, K.E.; Scheibner, K.; Hofrichter, M. Regioselective preparation of 5-hydroxypropranolol and 4'-hydroxydiclofenac with a fungal peroxygenase. Bioorg. Med. Chem. Lett. 2009, 19, 3085-3087. [CrossRef]

50. Poraj-Kobielska, M. Conversion of Pharmaceuticals and Other Drugs by Fungal Peroxygenases. Ph.D. Thesis, TU Dresden, Dresden, Germany, 2013.

51. Molina-Espeja, P.; Beltran-Nogal, A.; Alfuzzi, M.A.; Guallar, V.; Alcalde, M. Mapping potential determinants of peroxidative activity in an evolved fungal peroxygenase from Agrocybe aegerita. Front. Bioeng. Biotechnol. 2021, 9, 1282. [CrossRef]

52. Martin-Diaz, J.; Molina-Espeja, P.; Hofrichter, M.; Hollmann, F.; Alcalde, M. Directed evolution of unspecific peroxygenase in organic solvents. Biotechnol. Bioeng. 2021, 118, 3002-3014. [CrossRef]

53. Molina-Espeja, P.; Santos-Moriano, P.; García-Ruiz, E.; Ballesteros, A.; Plou, F.J.; Alcalde, M. Structure-guided immobilization of an evolved unspecific peroxygenase. Int. J. Mol. Sci. 2019, 20, 1627. [CrossRef]

54. Tonin, F.; Tieves, F.; Willot, S.; van Troost, A.; van Oosten, R.; Breestraat, S.; van Pelt, S.; Alcalde, M.; Hollmann, F. Pilot-Scale poduction of peroxygenase from Agrocybe aegerita. Org. Process. Res. Dev. 2021, 25, 1414-1418. [CrossRef]

55. Bormann, S.; Kellner, H.; Hermes, J.; Herzog, R.; Ullrich, R.; Liers, C.; Ulber, R.; Holtmann, D. Broadening the biocatalytic toolbox-Screening and expression of new unspecific peroxygenases. Antioxidants 2022, under review.

56. Pickard, M.A.; Kadima, T.A.; Carmichael, R.D. Chloroperoxidase, a peroxidase with potential. J. Ind. Microbiol. 1991, 7, $235-241$. [CrossRef]

57. Morris, D.R.; Hager, L.P. Chloroperoxidase: I. Isolation and properties of the chrystaline glycoprotein. J. Biol. Chem. 1966, 241, 1763-1768. [CrossRef]

58. Sae, A.S.W.; Cunningham, B.A. Isolation and properties of chloroperoxidase isozymes. Phytochemistry 1979, 18, 1785-1787. [CrossRef]

59. Conesa, A.; van de Velde, F.; van Rantwijk, F.; Sheldon, R.A.; van den Hondel, C.A.M.J.J.; Punt, P.J. Expression of the Caldariomyces fumago chloroperoxidase in Aspergillus niger and characterization of the recombinant enzyme. J. Biol. Chem. 2001, 276, 17635-17640. [CrossRef] [PubMed]

60. Linde, D.; Olmedo, A.; González-Benjumea, A.; Estévez, M.; Renau-Mínguez, C.; Carro, J.; Fernández-Fueyo, E.; Gutiérrez, A.; Martínez, A.T. Two new unspecific peroxygenases from heterologous expression of fungal genes in Escherichia coli. Appl. Environ. Microbiol. 2020, 86, e02899-19. [CrossRef] [PubMed]

61. Rotilio, L.; Swoboda, A.; Ebner, K.; Rinnofner, C.; Glieder, A.; Kroutil, W.; Mattevi, A. Structural and biochemical studies enlighten the unspecific peroxygenase from Hypoxylon sp. EC38 as an efficient oxidative biocatalyst. ACS Catal. 2021, 11, 11511-11525. [CrossRef]

62. Olmedo, A.; Río, J.C.d.; Kiebist, J.; Ullrich, R.; Hofrichter, M.; Scheibner, K.; Martínez, A.T.; Gutiérrez, A. Fatty acid chain shortening by a fungal peroxygenase. Chem. Eur. J. 2017, 23, 16985-16989. [CrossRef]

63. Kimani, V.W. New Secretory Peroxidases and Peroxygenases from Saprotrophic Fungi of Kenyan Forests. Ph.D. Thesis, TU Dresden, Dresden, Germany, 2019.

64. Gomez de Santos, P.; Hoang, M.D.; Kiebist, J.; Kellner, H.; Ullrich, R.; Scheibner, K.; Hofrichter, M.; Liers, C.; Alcalde, M. Functional expression of two unusual acidic peroxygenases from Candolleomyces aberdarensis in yeasts by adopting evolved secretion mutations. Appl. Environ. Microbiol. 2021, 87, e0087821. [CrossRef]

65. Püllmann, P.; Knorrscheidt, A.; Münch, J.; Palme, P.R.; Hoehenwarter, W.; Marillonnet, S.; Alcalde, M.; Westermann, B.; Weissenborn, M.J. A modular two yeast species secretion system for the production and preparative application of unspecific peroxygenases. Commun. Biol. 2021, 4, 562. [CrossRef]

66. Knorrscheidt, A.; Soler, J.; Hünecke, N.; Püllmann, P.; Garcia-Borràs, M.; Weissenborn, M.J. Accessing chemo- and regioselective benzylic and aromatic oxidations by protein engineering of an unspecific peroxygenase. ACS Catal. 2021, 11, 7327-7338. [CrossRef]

67. Püllmann, P.; Weissenborn, M.J. Improving the heterologous production of fungal peroxygenases through an episomal Pichia pastoris promoter and signal peptide shuffling system. ACS Synth. Biol. 2021, 10, 1360-1372. [CrossRef]

68. Berka, R.M.; Grigoriev, I.V.; Otillar, R.; Salamov, A.; Grimwood, J.; Reid, I.; Ishmael, N.; John, T.; Darmond, C.; Moisan, M.-C.; et al. Comparative genomic analysis of the thermophilic biomass-degrading fungi Myceliophthora thermophila and Thielavia terrestris. Nat. Biotechnol. 2011, 29, 922-927. [CrossRef]

69. Singh, B. Myceliophthora thermophila syn. Sporotrichum thermophile: A thermophilic mould of biotechnological potential. Crit. Rev. Biotechnol. 2016, 36, 59-69. [CrossRef]

70. Cregg, J.M.; Tolstorukov, I.; Kusari, A.; Sunga, J.; Madden, K.; Chappell, T. Expression in the yeast Pichia pastoris. In Methods in Enzymology, 2nd ed.; Burgess, R.R., Deutscher, M.P., Eds.; Academic Press: Cambridge, MA, USA, 2009; Volume 463, pp. 169-189.

71. Karich, A.; Kleeberg, S.; Ullrich, R.; Hofrichter, M. Enzymatic preparation of 2,5-furandicarboxylic acid (FDCA)—A substitute of terephthalic acid-By the joined action of three fungal enzymes. Microorganisms 2018, 6, 5. [CrossRef]

72. Kinner, A.; Rosenthal, K.; Lütz, S. Identification and expression of new unspecific peroxygenases-Recent advances, challenges and opportunities. Front. Bioeng. Biotechnol. 2021, 9, 5630. [CrossRef]

73. Chong, S. Overview of cell-free protein synthesis: Historic landmarks, commercial Systems, and expanding applications. Curr. Protoc. Mol. Biol. 2014, 108, 16-30. [CrossRef]

74. Dondapati, S.K.; Stech, M.; Zemella, A.; Kubick, S. Cell-free protein synthesis: A promising option for future drug development. BioDrugs 2020, 34, 327-348. [CrossRef] 
75. Karich, A.; Scheibner, K.; Ullrich, R.; Hofrichter, M. Exploring the catalase activity of unspecific peroxygenases and the mechanism of peroxide-dependent heme destruction. J. Mol. Catal. B Enzym. 2016, 134, 238-246. [CrossRef]

76. Munro, A.W.; Girvan, H.M.; McLean, K.J. Variations on a (t)heme-novel mechanisms, redox partners and catalytic functions in the cytochrome P450 superfamily. Nat. Prod. Rep. 2007, 24, 585-609. [CrossRef]

77. Piontek, K.; Ullrich, R.; Liers, C.; Diedrichs, K.; Plattner, A.D.; Hofrichter, M. Crystallization of a 45 kDa peroxygenase/peroxidase from the mushroom Agrocybe aegerita and structure determination by SAD utilizing only the haem iron. Acta Crystallogr. F Struct. Biol. Commun. Commun. 2010, 66, 693-698. [CrossRef]

78. Mirdita, M.; Schütze, K.; Moriwaki, Y.; Heo, L.; Ovchinnikov, S.; Steinegger, M. ColabFold—Making protein folding accessible to all. bioRxiv 2021. [CrossRef]

79. Jumper, J.; Evans, R.; Pritzel, A.; Green, T.; Figurnov, M.; Ronneberger, O.; Tunyasuvunakool, K.; Bates, R.; Žídek, A.; Potapenko, A.; et al. Highly accurate protein structure prediction with AlphaFold. Nature 2021, 596, 583-589. [CrossRef]

80. Janson, G.; Paiardini, A. PyMod 3: A complete suite for structural bioinformatics in PyMOL. Bioinformatics 2020, 37, 1471-1472. [CrossRef] [PubMed]

81. Šali, A.; Blundell, T.L. Comparative protein modelling by satisfaction of spatial restraints. J. Mol. Biol. 1993, 234, 779-815. [CrossRef] [PubMed]

82. Paiardini, A.; Bossa, F.; Pascarella, S. CAMPO, SCR_FIND and CHC_FIND: A suite of web tools for computational structural biology. Nucleic Acids Res. 2005, 33, W50-W55. [CrossRef] [PubMed]

83. Martinez, X.; Krone, M.; Alharbi, N.; Rose, A.S.; Laramee, R.S.; O’Donoghue, S.; Baaden, M.; Chavent, M. Molecular graphics: Bridging structural biologists and computer scientists. Structure 2019, 27, 1617-1623. [CrossRef]

84. Hameduh, T.; Haddad, Y.; Adam, V.; Heger, Z. Homology modeling in the time of collective and artificial intelligence. Comput. Struct. Biotechnol. J. 2020, 18, 3494-3506. [CrossRef]

85. Poraj-Kobielska, M.; Kinne, M.; Ullrich, R.; Scheibner, K.; Kayser, G.; Hammel, K.E.; Hofrichter, M. Preparation of human drug metabolites using fungal peroxygenases. Biochem. Pharmacol. 2011, 82, 789-796. [CrossRef]

86. Karich, A.; Ullrich, R.; Scheibner, K.; Hofrichter, M. Fungal unspecific peroxygenases oxidize the majority of organic EPA priority pollutants. Front. Microbiol. 2017, 8, 1463. [CrossRef]

87. Wang, X.; Ullrich, R.; Hofrichter, M.; Groves, J.T. Heme-thiolate ferryl of aromatic peroxygenase is basic and reactive. Proc. Natl. Acad. Sci. USA 2015, 112, 3686-3691. [CrossRef]

88. Kinne, M.; Zeisig, C.; Ullrich, R.; Kayser, G.; Hammel, K.E.; Hofrichter, M. Stepwise oxygenations of toluene and 4-nitrotoluene by a fungal peroxygenase. Biochem. Biophys. Res. Commun. 2010, 397, 18-21. [CrossRef]

89. Kinne, M.; Poraj-Kobielska, M.; Ralph, S.A.; Ullrich, R.; Hofrichter, M.; Hammel, K.E. Oxidative cleavage of diverse ethers by an extracellular fungal peroxygenase. J. Biol. Chem. 2009, 284, 29343-29349. [CrossRef]

90. Kluge, M.; Ullrich, R.; Scheibner, K.; Hofrichter, M. Stereoselective benzylic hydroxylation of alkylbenzenes and epoxidation of styrene derivatives catalyzed by the peroxygenase of Agrocybe aegerita. Green Chem. 2012, 14, 440-446. [CrossRef]

91. Huang, X.; Groves, J.T. Beyond ferryl-mediated hydroxylation: 40 years of the rebound mechanism and C-H activation. J. Biol. Inorg. Chem. 2017, 22, 185-207. [CrossRef]

92. Shalan, H.; Kato, M.; Cheruzel, L. Keeping the spotlight on cytochrome P450. Biochim. Biophys. Acta Proteins Proteom. BBA 2018, 1866, 80-87. [CrossRef]

93. Bormann, S.; Gomez Baraibar, A.; Ni, Y.; Holtmann, D.; Hollmann, F. Specific oxyfunctionalisations catalysed by peroxygenases: Opportunities, challenges and solutions. Catal. Sci. Technol. 2015, 5, 2038-2052. [CrossRef]

94. Hofrichter, M.; Ullrich, R. New Trends in Fungal Biooxidation. In Industrial Applications; Hofrichter, M., Ed.; Springer: Heidelberg, Germany, 2011; pp. 425-449.

95. Ullrich, R.; Hofrichter, M. Enzymatic hydroxylation of aromatic compounds. Cell. Mol. Life Sci. 2007, 64, 271-293. [CrossRef]

96. Wang, Y.; Lan, D.; Durrani, R.; Hollmann, F. Peroxygenases en route to becoming dream catalysts. What are the opportunities and challenges? Curr. Opin. Chem. Biol. 2017, 37, 1-9. [CrossRef]

97. Aranda, C.; Carro, J.; González-Benjumea, A.; Babot, E.D.; Olmedo, A.; Linde, D.; Martínez, A.T.; Gutiérrez, A. Advances in enzymatic oxyfunctionalization of aliphatic compounds. Biotechnol. Adv. 2021, 51, 107703. [CrossRef]

98. Peng, L.; Wollenberger, U.; Kinne, M.; Hofrichter, M.; Ullrich, R.; Scheibner, K.; Fischer, A.; Scheller, F.W. Peroxygenase based sensor for aromatic compounds. Biosens. Bioelectron. 2010, 26, 1432-1436. [CrossRef]

99. Yarman, A.; Gröbe, G.; Neumann, B.; Kinne, M.; Gajovic-Eichelmann, N.; Wollenberger, U.; Hofrichter, M.; Ullrich, R.; Scheibner, K.; Scheller, F.W. The aromatic peroxygenase from Marasmius rotula-A new enzyme for biosensor applications. Anal. Bioanal. Chem. 2012, 402, 405-412. [CrossRef]

100. Grogan, G. Hemoprotein catalyzed oxygenations: P450s, UPOs, and progress toward scalable reactions. JACS Au 2021, 1, 13121329. [CrossRef]

101. Wapshott-Stehli, H.L.; Grunden, A.M. In situ $\mathrm{H}_{2} \mathrm{O}_{2}$ generation methods in the context of enzyme biocatalysis. Enzym. Microb. Technol. 2021, 145, 109744. [CrossRef]

102. Friedrich, S.; Gröbe, G.; Kluge, M.; Brinkmann, T.; Hofrichter, M.; Scheibner, K. Optimization of a biocatalytic process to gain (R)-1-phenylethanol by applying the software tool Sabento for ecological assessment during the early stages of development. J. Mol. Catal. B Enzym. 2014, 103, 36-40. [CrossRef] 
103. Peter, S.; Kinne, M.; Wang, X.; Ullrich, R.; Kayser, G.; Groves, J.T.; Hofrichter, M. Selective hydroxylation of alkanes by an extracellular fungal peroxygenase. FEBS J. 2011, 278, 3667-3675. [CrossRef]

104. Peter, S.; Karich, A.; Ullrich, R.; Gröbe, G.; Scheibner, K.; Hofrichter, M. Enzymatic one-pot conversion of cyclohexane into cyclohexanone: Comparison of four fungal peroxygenases. J. Mol. Catal. B Enzym. 2014, 103, 47-51. [CrossRef]

105. Kiebist, J.; Holla, W.; Heidrich, J.; Poraj-Kobielska, M.; Sandvoss, M.; Simonis, R.; Gröbe, G.; Atzrodt, J.; Hofrichter, M.; Scheibner, K. One-pot synthesis of human metabolites of SAR548304 by fungal peroxygenases. Bioorg. Med. Chem. 2015, 23, 4324-4332. [CrossRef]

106. Karich, A.; Kluge, M.; Ullrich, R.; Hofrichter, M. Benzene oxygenation and oxidation by the peroxygenase of Agrocybe aegerita. $A M B$ Express 2013, 3, 5. [CrossRef]

107. Aranda, C.; Ullrich, R.; Kiebist, J.; Scheibner, K.; del Río, J.C.; Hofrichter, M.; Martínez, A.T.; Gutiérrez, A. Selective synthesis of the resveratrol analogue $4,4^{\prime}$-dihydroxy-trans-stilbene and stilbenoids modification by fungal peroxygenases. Catal. Sci. Technol. 2018, 8, 2394-2401. [CrossRef]

108. Kluge, M.; Ullrich, R.; Dolge, C.; Scheibner, K.; Hofrichter, M. Hydroxylation of naphthalene by aromatic peroxygenase from Agrocybe aegerita proceeds via oxygen transfer from $\mathrm{H}_{2} \mathrm{O}_{2}$ and intermediary epoxidation. Appl. Microbiol. Biotechnol. 2009, 81, 1071-1076. [CrossRef]

109. Aranda, E.; Ullrich, R.; Hofrichter, M. Conversion of polycyclic aromatic hydrocarbons, methyl naphthalenes and dibenzofuran by two fungal peroxygenases. Biodegradation 2010, 21, 267-281. [CrossRef]

110. Peter, S.; Kinne, M.; Ullrich, R.; Kayser, G.; Hofrichter, M. Epoxidation of linear, branched and cyclic alkenes catalyzed by unspecific peroxygenase. Enzym. Microb. Technol. 2013, 52, 370-376. [CrossRef]

111. Carro, J.; González-Benjumea, A.; Fernández-Fueyo, E.; Aranda, C.; Guallar, V.; Gutiérrez, A.; Martínez, A.T. Modulating fatty acid epoxidation vs hydroxylation in a fungal peroxygenase. ACS Catal. 2019, 9, 6234-6242. [CrossRef]

112. Peter, S. Oxyfunctionalization of Alkanes, Alkenes and Alkynes by Unspecific Peroxygenase (EC 1.11.2.1). Ph.D. Thesis, TU Dresden, Dresden, Germany, 2013.

113. Municoy, M.; González-Benjumea, A.; Carro, J.; Aranda, C.; Linde, D.; Renau-Mínguez, C.; Ullrich, R.; Hofrichter, M.; Guallar, V.; Gutiérrez, A.; et al. Fatty-acid oxygenation by fungal peroxygenases: From computational simulations to preparative regio- and stereoselective epoxidation. ACS Catal. 2020, 10, 13584-13595. [CrossRef]

114. González-Benjumea, A.; Marques, G.; Herold-Majumdar, O.M.; Kiebist, J.; Scheibner, K.; del Río, J.C.; Martínez, A.T.; Gutiérrez, A High epoxidation yields of vegetable oil hydrolyzates and methyl esters by selected fungal peroxygenases. Front. Bioeng. Biotechnol. 2021, 8, 1470. [CrossRef] [PubMed]

115. González-Benjumea, A.; Carro, J.; Renau-Mínguez, C.; Linde, D.; Fernández-Fueyo, E.; Gutiérrez, A.; Martínez, A.T. Fatty acid epoxidation by Collariella virescens peroxygenase and heme-channel variants. Catal. Sci. Technol. 2020, 10, 717-725. [CrossRef]

116. Ullrich, R.; Dolge, C.; Kluge, M.; Hofrichter, M. Pyridine as novel substrate for regioselective oxygenation with aromatic peroxygenase from Agrocybe aegerita. FEBS Lett. 2008, 582, 4100-4106. [CrossRef] [PubMed]

117. Kinne, M. The Extracellular Peroxygenase of the Agaric Fungus Agrocybe aegerita: Catalytic Properties and Physiological Background with Particular Emphasis on Ether Cleavage. Ph.D. Thesis, International Graduate School of Zittau, Zittau, Germany, 2010.

118. Wu, Y.; Wollenberger, U.; Hofrichter, M.; Ullrich, R.; Scheibner, K.; Scheller, F.W. Direct electron transfer of Agrocybe aegerita peroxygenase at electrodes modified with chitosan-capped Au nanoparticles and its bioelectrocatalysis to aniline. Sens. Actuators B Chem. 2011, 160, 1419-1426. [CrossRef]

119. Bassanini, I.; Ferrandi, E.E.; Vanoni, M.; Ottolina, G.; Riva, S.; Crotti, M.; Brenna, E.; Monti, D. Peroxygenase-catalyzed enantioselective sulfoxidations. Eur. J. Org. Chem. 2017, 2017, 7186-7189. [CrossRef]

120. Li, Y.; Ma, Y.; Li, P.; Zhang, X.; Ribitsch, D.; Alcalde, M.; Hollmann, F.; Wang, Y. Enantioselective sulfoxidation of thioanisole by cascading a choline oxidase and a peroxygenase in the presence of natural deep eutectic solvents. ChemPlusChem 2020, 85, 254-257. [CrossRef]

121. Aranda, E.; Kinne, M.; Kluge, M.; Ullrich, R.; Hofrichter, M. Conversion of dibenzothiophene by the mushrooms Agrocybe aegerita and Coprinellus radians and their extracellular peroxygenases. Appl. Microbiol. Biotechnol. 2009, 82, 1057-1066. [CrossRef]

122. Ullrich, R.; Hofrichter, M. The haloperoxidase of the agaric fungus Agrocybe aegerita hydroxylates toluene and naphthalene. FEBS Lett. 2005, 579, 6247-6250. [CrossRef]

123. Dembitsky, V.M. Oxidation, epoxidation and sulfoxidation reactions catalysed by haloperoxidases. Tetrahedron 2003, 59, 4701-4720. [CrossRef]

124. Kinne, M.; Poraj-Kobielska, M.; Ullrich, R.; Nousiainen, P.; Sipilä, J.; Scheibner, K.; Hammel, K.E.; Hofrichter, M. Oxidative cleavage of non-phenolic $\beta-\mathrm{O}-4$ lignin model dimers by an extracellular aromatic peroxygenase. Holzforschung 2011, 65, 673-679. [CrossRef]

125. Forsberg, Z.; Sørlie, M.; Petrović, D.; Courtade, G.; Aachmann, F.L.; Vaaje-Kolstad, G.; Bissaro, B.; Røhr, Å.K.; Eijsink, V.G.H. Polysaccharide degradation by lytic polysaccharide monooxygenases. Curr. Opin. Struct. Biol. 2019, 59, 54-64. [CrossRef]

126. Lara, E.; Moreira, D.; López-García, P. The environmental clade LKM11 and Rozella form the deepest branching clade of fungi. Protist 2010, 161, 116-121. [CrossRef] 
127. Morin, E.; Kohler, A.; Baker, A.R.; Foulongne-Oriol, M.; Lombard, V.; Nagy, L.G.; Ohm, R.A.; Patyshakuliyeva, A.; Brun, A.; Aerts, A.L.; et al. Genome sequence of the button mushroom Agaricus bisporus reveals mechanisms governing adaptation to a humic-rich ecological niche. Proc. Natl. Acad. Sci. 2012, 109, 17501-17506. [CrossRef]

128. O'Connor, E.; McGowan, J.; McCarthy, C.G.P.; Amini, A.; Grogan, H.; Fitzpatrick, D.A. Whole genome sequence of the commercially relevant mushroom strain Agaricus bisporus var. bisporus ARP23. G3 2019, 9, 3057-3066. [CrossRef]

129. Savory, F.; Leonard, G.; Richards, T.A. The role of horizontal gene transfer in the evolution of the oomycetes. PLoS Pathog. 2015, 11, e1004805. [CrossRef]

130. Liang, D.; Andersen, C.B.; Vetukuri, R.R.; Dou, D.; Grenville-Briggs, L.J. Horizontal gene transfer and tandem duplication shape the unique CAZyme complement of the mycoparasitic oomycetes Pythium oligandrum and Pythium periplocum. Front. Microbiol. 2020, 11, 1698. [CrossRef]

131. Price, M.N.; Dehal, P.S.; Arkin, A.P. FastTree: Computing Large Minimum Evolution Trees with Profiles instead of a Distance Matrix. Mol. Biol. Evol. 2009, 26, 1641-1650. [CrossRef]

132. Kendrick, B. The Fifth Kingdom, 3rd ed.; Focus Publishing: New York, NY, USA, 2000.

133. Danielson, P.B. The cytochrome P450 superfamily: Biochemistry, evolution and drug metabolism in humans. Curr. Drug Metab. 2002, 3, 561-597. [CrossRef]

134. Hlavica, P. Evaluation of structural features in fungal cytochromes P450 predicted to rule catalytic diversification. Biochim. Biophys. Acta Proteins Proteom. BBA 2013, 1834, 205-220. [CrossRef] [PubMed]

135. Lewis, D.F.V.; Sheridan, G. Cytochromes P450, oxygen, and evolution. Sci. World J. 2001, 1, 698519. [CrossRef] [PubMed]

136. Kalum, L.; Lund, H.; Hofrichter, M.; Ullrich, R. Enzymatic Preparation of Indigo Dyes and Intermediates. EU Patent PCT/EP2014/052103, 5 February 2013.

137. Kont, R.; Bissaro, B.; Eijsink, V.G.H.; Väljamäe, P. Kinetic insights into the peroxygenase activity of cellulose-active lytic polysaccharide monooxygenases (LPMOs). Nat. Commun. 2020, 11, 5786. [CrossRef] [PubMed]

138. Rieder, L.; Stepnov, A.A.; Sørlie, M.; Eijsink, V.G.H. Fast and specific peroxygenase reactions catalyzed by fungal mono-copper enzymes. Biochemistry 2021, 60, 3633-3643. [CrossRef] [PubMed]

139. Kellner, H.; Luis, P.; Pecyna, M.J.; Barbi, F.; Kapturska, D.; Krüger, D.; Zak, D.R.; Marmeisse, R.; Vandenbol, M.; Hofrichter, M. Widespread occurrence of expressed fungal secretory peroxidases in forest soils. PLoS ONE 2014, 9, e95557. [CrossRef]

140. Leonhardt, S.; Hoppe, B.; Stengel, E.; Noll, L.; Moll, J.; Bässler, C.; Dahl, A.; Buscot, F.; Hofrichter, M.; Kellner, H. Molecular fungal community and its decomposition activity in sapwood and heartwood of 13 temperate European tree species. PLoS ONE 2019, 14, e0212120. [CrossRef] 